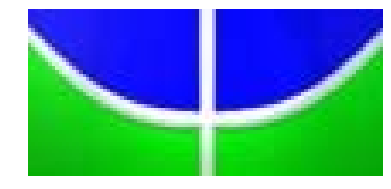

\author{
Universidade de Brasília - UnB \\ Instituto de Ciências Humanas - IH \\ Departamento de Serviço Social - SER
}

\title{
Os serviços de atendimento às mulheres vítimas de violência conjugal no DF: o olhar da equipe técnica do NUPS/SERAV (TJDFT)
}

Dayane Cristina Moreira Xavier.

Brasília

Abril de 2008. 


\section{Dayane Cristina Moreira Xavier.}

\section{Os serviços de atendimento às mulheres vítimas de violência conjugal no DF: o olhar da equipe técnica do NUPS/SERAV (TJDFT)}

Monografia realizada como requisito parcial à conclusão do curso de Serviço Social do Instituto de Ciências Humanas da Universidade de Brasília, para a obtenção do grau de assistente social.

Orientadora: Prof. a Marlene Teixeira Rodrigues.

Brasília

Abril de 2008 
Dedico esta monografia aos meus pais: Arnaldo e Mirian, pelo amor, dedicação, apoio e confiança em todos os momentos. E por viverem este sonho comigo.

Aos meus queridos irmãos, Marcus Vinícius e Fabrício, pelo incentivo e amizade de sempre. Aos meus avós: Francisco (in memoriam), Maria, Antônio e Matilde, por toda a sabedoria, simplicidade e estímulo nesta longa caminhada. Aos meus familiares, por me apoiarem em vários momentos de dificuldade.

Ao doce Igor, pela compreensão da distância e por todo o amor e companheirismo. 


\section{Agradecimentos}

Agradeço primeiramente a Deus e a Nossa Senhora por terem me abençoado durante essa caminhada e por me permitirem esta conquista.

A toda minha família (pais, tios (as), primos (as), avós, irmãos, cunhados (as), afilhados, 'sobrinhos' e namorado) pelo incentivo, amor e amizade. E de maneira especial agradeço meus padrinhos, Sônia e Manoel por todo o carinho. E também aos meus tios: Celina, Osvaldo, Mirênia, Celeste, Roberto (Dito) e Valda, pois sem eles essa vitória não seria possível.

As minhas amigas-irmãs: Giselle, Thaís, Liliane, Poliana, Aline, Josiellen, Marcela, Vânia, Juliana, Loyane, Hairam, Vanessa e Karina, por todos os momentos previsíveis e imprevisíveis nesta caminhada.

Aos meus colegas Daniel e Stella, e aos demais colegas de curso e do movimento estudantil, pelo companheirismo na vida acadêmica. Agradeço especialmente os que leram e contribuíram com este trabalho.

Aos amigos de estágio, da Casa do Estudante - CEU e tantos outros, que direta e indiretamente contribuíram com a realização deste sonho.

Agradeço de maneira especial minha orientadora professora doutora e coordenadora do Departamento de Serviço Social Marlene Teixeira Rodrigues, por toda a atenção, paciência e compreensão na construção deste trabalho.

À professora Izis Morais Lopes dos Reis, pela disponibilidade em participar da banca de defesa desta monografia.

À assistente social e mestre Lianne Carvalho de Oliveira pela grande dedicação, aprendizado cotidiano, supervisão no estágio e por também fazer parte da banca.

A todos os técnicos, supervisores (Sérgio, Lianne, Márcia Borba, Regina e Marilza e Marília), estagiários e grupo da secretária da SEPS no Tribunal de Justiça do Distrito Federal e Territórios, por todas as oportunidades, aprendizado construído e amizade de sempre. 


\section{Resumo}

O presente trabalho analisa os serviços de atendimento às mulheres vítimas de violência conjugal no Distrito Federal - DF, tendo como referência as e os profissionais que atuam no Serviço de Atendimento às Famílias em Situação de Violência - SERAV do Tribunal de Justiça do Distrito Federal e Territórios - TJDFT, dentre os quais se incluem assistentes sociais, psicólogos/as e uma antropóloga e socióloga. Com o objetivo de viabilizar o estudo definiu-se por investigar os processos referentes às mulheres atendidas pelo NUPS/SERAV, principalmente às vítimas de violência conjugal, e cuja entrada no serviço aconteceu entre os meses de novembro de 2006 a janeiro de 2007, e o encerramento procedeu até novembro de 2007 quando se iniciou a pesquisa de campo. Tendo como marco referencial para a discussão a categoria violência, tratada no primeiro capítulo da monografia, e os avanços logrados pelo movimento feminista brasileiro na criação de políticas específicas para as mulheres, em especial a Lei “Maria da Penha”, a pesquisa empírica focalizou o atendimento prestado às mulheres, encaminhadas pela $1^{\mathrm{a}}$ Vara de Violência Doméstica e Familiar de Brasília, mediante a análise das pastas e dos relatórios de acompanhamento, produzidos pelo pessoal técnico do SERAV, e a realização de entrevistas com os/as profissionais lotados/as no setor, que atuaram nos referidos processos. A análise dos dados, que se apresenta no último capítulo, mostrou que das 61 mulheres vítimas de violência doméstica e familiar, integrantes de nossa amostra, 54\% sofre(ra)m violência conjugal. Em termos de perfil socioeconômico e cultural: 86\% residem em cidades satélites e 47\% encontram-se empregadas. Quanto aos serviços e instituições do Distrito Federal que atendem as mulheres vítimas de violência, 70\% dos/as técnicos/as entrevistados/as do NUPS/SERAV apresentaram críticas ou sugestões relacionadas a estes. Entre as principais críticas podemos destacar a falta de articulação e contato entre os vários serviços/ínstituições que atendem as mulheres vítimas de violência conjugal e a justiça. Como sugestão os/as técnicos trazem a ampliação dos serviços e instituições existentes para outras cidades satélites de Brasília.

Palavras-chaves: Violência conjugal, Gênero, Lei “Maria da Penha”, movimento feminista e intervenção em rede. 


\section{Sumário}

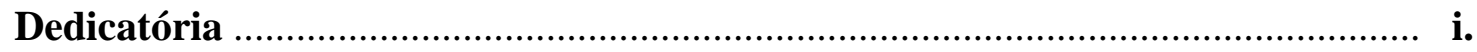

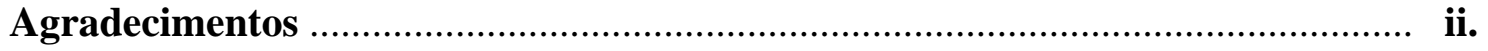

Resumo …........................................................................................... iii.

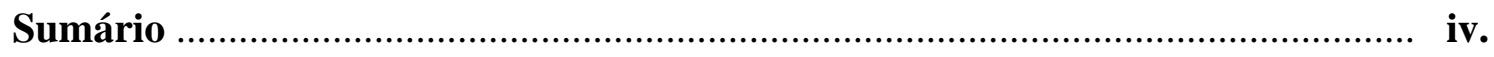

Lista de Siglas ............................................................................................ vi.

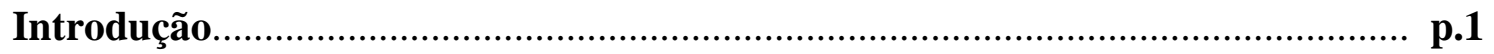

Capítulo 1 - Percurso Metodológico - a delimitação do tema e do objeto

p.4

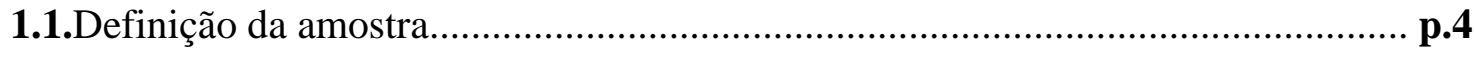

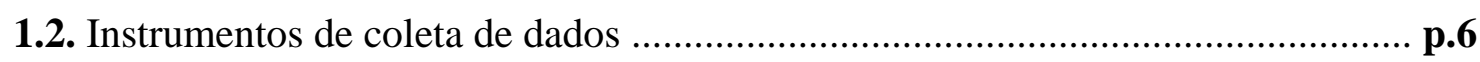

1.3.A realização da pesquisa de campo ..................................................................... p.7

Capítulo 2 - Violência: aproximação conceitual .................................................... p.9

2.1. A violência: um fenômeno de múltiplas dimensões .............................................. p.10

2.2. A violência na conjugalidade na perspectiva de gênero ………………………..... p.14

Capítulo 3 - O Movimento Feminista e a Construção de Políticas Públicas para as

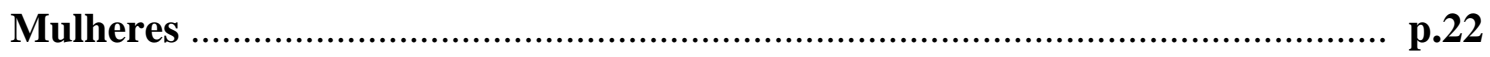

3.1. Caracterização e contextualização histórica do Movimento Feminista ............. p.22

3.2. Movimento Feminista e Políticas Públicas para as Mulheres.............................. p.28

Capítulo 4 - A Lei “Maria da Penha” e importância da articulação de redes... p.36

4.1. As inovações da Lei $\mathrm{n}^{0}$. 11.340/2006 .............................................................. p.39

4.2. A importância da articulação de redes ................................................................ p.46

Capítulo 5 - Os serviços de atendimento às mulheres vítimas de violência conjugal do

DF na perspectiva da equipe do SERAV ........................................................ p.49

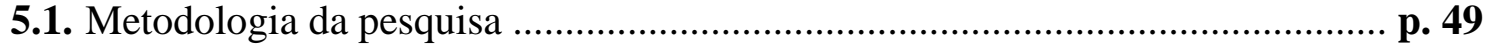

5.2. O Serviço de Atendimento às Famílias em Situação de Violência - SERAV do Tribunal de Justiça do Distrito Federal e Territórios - TJDFT .................................... p. 50

5.3. Perfil da Equipe Técnica do SERAV ………………………………………..... p. 52 
5.4. O perfil socioeconômico e cultural das mulheres vítimas de violência conjugal atendidas no NUPS/SERAV do TJDFT

p. 54

5.5. As instituições de defesa da mulher existentes no Distrito Federal mais acionadas pelo NUPS/SERAV

\section{p. 62}

5.6. As instituições que mais ajudaram a modificar a situação de violência: a opinião da equipe do NUPS/SERAV

p. 65

5.7. Avaliação dos procedimentos de encaminhamento: o olhar dos/as técnicos

p. 69

5.8. A análise dos serviços de atendimento às mulheres vítimas de violência conjugal do Distrito Federal: a constituição de uma rede?

p. 70

Considerações Finais

p.73

Referências Bibliográficas

p. 75

Anexos

p.79 


\section{Lista de Siglas}

BID - Banco Internacional de Desenvolvimento;

CAPS/AD - Centro de Atenção Psicossocial de Álcool e outras Drogas;

CDM - Conselho dos Direitos da Mulher;

CEDAW - Convenção sobre a Eliminação de Todas as Formas de Discriminação contra a Mulher

CFEMEA - Centro Feminista de Estudos e Assessoria;

CLADEM - Comitê Latino Americano e do Caribe para a Defesa dos Direitos da Mulher; CNDM - Conselho Nacional dos Direitos da Mulher;

DEAM - Delegacia de Atendimento a Mulher;

DF - Distrito Federal;

GDF - Governo do Distrito Federal;

JECRIMS - Juizados Especiais Criminais do Distrito Federal;

JECS - Juizados Especiais Cíveis do Distrito Federal;

JUFAM - Vara do Juizado de Violência Doméstica e Familiar contra a Mulher de Brasília;

NUPS - Núcleo Psicossocial Forense;

PNPM - Plano Nacional de Políticas para as Mulheres;

ONGs - Organizações Não-Governamentais;

ONU - Organização das Nações Unidas;

SBPC - Sociedade Brasileira para o Progresso da Ciência

SEPAVI - Seção de Atenção Psicossocial de Violência Intrafamiliar;

SERPEQ - Serviço de Pesquisa;

SEPS - Seção Psicossocial de Atenção Psicossocial aos Usuários de Substâncias;

SEPSI - Secretária Psicossocial Judiciária;

SEDIM - Secretaria de Estado dos Direitos da Mulher;

SPM - Secretária Especial de Políticas para as Mulheres;

SERAV - Serviço de Atendimento às Famílias em Situação de Violência;

TJDFT - Tribunal de Justiça do Distrito Federal e Territórios; 


\section{Introdução}

Este trabalho é o produto final da disciplina de graduação Trabalho de Conclusão de Curso - TCC, e representa a avaliação final para a obtenção do grau de assistente social. Tal disciplina foi oferecida, no segundo semestre de 2007, pelo Departamento de Serviço Social da Universidade de Brasília - UnB.

Vale ressaltar que esta monografia delineou-se a partir dos trabalhos desenvolvidos pela autora durante o percurso da graduação, e principalmente do estágio realizado no Serviço de Atendimento às Famílias em Situação de Violência - SERAV, do Tribunal de Justiça do Distrito Federal e Territórios, órgão criado com a extinção do Núcleo Psicossocial Forense - NUPS, onde se iniciou a experiência do estágio. A vivência deste estágio proporcionou o acompanhamento de inúmeros processos relacionados à violência doméstica e familiar contra a mulher e despertou o interesse de aprofundar a reflexão nesse campo. Outro fato motivador para delimitação do objeto de pesquisa foi à promulgação da Lei $\mathrm{n}^{\circ}$. 11.340/2006 e também a importância contida em cada um dos seus respectivos artigos.

A Lei $n^{\circ}$. 11.340, sancionada em agosto de 2006, ficou popularmente conhecida pelo nome de “Lei Maria da Penha”. Tal nome é uma homenagem à mulher, de mesmo nome, que lutou durante 20 anos para que seu ex-marido (ex-professor universitário) fosse realmente punido, após este tentar assassiná-la por duas vezes: uma vez com arma de fogo e na outra vez tentou afogá-la e eletrocutá-la.

A violência e as tentativas de homicídio perpetradas contra esta mulher geraram conseqüências irreversíveis à sua saúde, como, por exemplo, a paraplegia, além de outras seqüelas. Mas todos estes fatos não impediram Maria da Penha de transformar toda a sua dor em luta, e ela tornou-se uma incansável militante “em prol dos direitos das mulheres” (MEC, 2007, p. 37).

Com o apoio de grupos feministas, Maria da Penha, conseguiu que seu caso fosse levado até as últimas instâncias, nacionais e internacionais de direitos humanos da ONU, e com isso decretar a prisão de seu agressor (BRASIL, 2006). Assim pode-se conceber que a criação de políticas públicas destinadas a erradicar as formas de violência contra a mulher e 
a própria promulgação da lei “Maria da Penha”, possuem em seu cerne uma relação direta com o movimento feminista.

Neste trabalho focalizamos as inovações estabelecidas pela Lei $n^{0}$. 11.340/2006, principalmente as relacionadas à criação e articulação entre os diversos serviços, políticas e programas, que atendem as mulheres vítimas de violência doméstica e familiar, no DF. O foco geral da monografia consiste em sistematizar informações sobre os serviços que atendem as mulheres vítimas de violência conjugal no DF. Ademais com a realização deste estudo se pretendeu:

- apresentar o Serviço de Atendimento às Famílias em Situação de Violência SERAV, do Tribunal de Justiça do Distrito Federal e Territórios;

- traçar o perfil da equipe técnica multiprofissional que integra o SERAV;

- descrever o perfil socioeconômico e cultural das mulheres vítimas de violência conjugal atendidas pela equipe do SERAV, no período delimitado;

- descrever os serviços de atendimento das mulheres vítimas de violência conjugal existentes no DF e acionados pela equipe do SERAV;

- conhecer a percepção dos técnicos do SERAV sobre os serviços de atendimento das mulheres vítimas de violência conjugal no DF, aos quais o Serviço recorre.

A pergunta que procuramos responder nesta monografia é: Quais os serviços que atendem as mulheres vítimas de violência conjugal são identificados e acionados pela equipe técnica do SERAV? A hipótese adotada no presente trabalho é que a equipe técnica do SERAV dispõe de poucos serviços para atendimento das mulheres vítimas de violência conjugal e que estes não estão articulados em uma rede orgânica, que vincule a justiça e as demais instituições, envolvidas no processo.

Assim, a pesquisa desta monografia foi realizada no Serviço de Atendimento às Famílias em Situação de Violência - SERAV do Tribunal de Justiça do Distrito Federal e Territórios - TJDFT. Anteriormente, este serviço consistia, em uma das seções do Núcleo Psicossocial Forense - NUPS. A delimitação do NUPS/SERAV como local de pesquisa, deve-se ao acompanhamento de mulheres envolvidas em situação de violência doméstica e familiar, a maioria envolvendo casais ou ex-casais, realizado por este serviço. 
Outro fato relevante para a delimitação do NUPS/SERAV, como o recorte institucional/espacial para o desenvolvimento da monografia, deve-se ao acesso e contato que a pesquisadora poderia ter com as mulheres vítimas de violência conjugal, por intermédio da instituição, uma vez que autora atuou nesta como estagiária por mais ou menos 02 anos.

O recorte temporal estabelecido foi entre os meses de novembro de 2006 a janeiro de 2007, de modo a abarcar os processos inaugurais da $1^{\text {a }}$ Vara do Juizado de Violência Doméstica e Familiar contra a Mulher de Brasília, cujo acompanhamento pelo NUPS/SERAV já havia sido encerrados no início da realização da pesquisa, e o respectivo relatório havia sido enviado a juíza responsável pelo mesmo.

A monografia está dividida em cinco capítulos, além da introdução e das considerações finais. O primeiro capítulo descreve o percurso metodológico e objetiva apresentar a delimitação do tema e do objetivo de pesquisa. Algumas questões colocadas neste capítulo são retomadas no último, que diz respeito à apresentação dos dados.

O segundo capítulo traz uma aproximação conceitual do termo violência em seus variados contextos, com atenção especial à violência na conjugalidade e a questão de gênero; este capítulo representa a base teórica do trabalho e para a análise dos dados encontrados na pesquisa.

No terceiro capítulo se analisa a história do movimento feminista, e a sua relação com a formulação de políticas públicas para as mulheres. Já o quarto foca na análise das inovações da lei “Maria da Penha”, com ênfase na criação e articulação das políticas e dos serviços, sendo também apresentados os conceitos de rede.

No quinto e último capítulo se apresenta os dados levantados sobre a estruturação e funcionamento do NUPS/SERAV, o perfil das/os integrantes da equipe técnica entrevistadas/os, os serviços que atenderam as mulheres vítimas de violência doméstica acionados pela equipe do NUPS/SERAV, assim como as considerações acerca da instituição de uma rede de atendimento, integrada por esses serviços/instituições, segundo a opinião dos/as técnicos/as do SERAV ouvidos/as na pesquisa. 


\section{CAPÍTULO 1 - Percurso Metodológico - a delimitação do tema e do objeto}

\subsection{Definição da amostra}

Este item destina-se a apresentar o caminho percorrido para o delineamento e a realização da pesquisa sobre os serviços de atendimento às mulheres vítimas de violência conjugal existentes no Distrito Federal - DF, apresentada no projeto de monografia.

O tema desta monografia foi escolhido, após a observação nos Grupos de Acolhimento e Pré-Audiência realizados com as mulheres vítimas de violência no NUPS/SERAV ${ }^{1}$ da Vara do Juizado de Violência Familiar e Doméstica contra a Mulher no TJDFT, durante o período de estágio supervisionado. Este setor tem a competência, no âmbito do TJDFT, de acompanhar as mulheres envolvidas em situação de violência conjugal.

Ao participar, na condição de estagiária, de todas as ações desenvolvidas pela equipe técnica do setor, durante quase 02 anos, foi possível observar nestes grupos as mulheres, principalmente as vítimas de violência conjugal, e as suas opiniões e críticas constantes sobre a maneira como eram atendidas e tratadas nas diferentes organizações governamentais e não-governamentais de Brasília. Em muitas situações, segundo depoimentos destas mulheres no grupo, elas se sentiam desencorajadas e com receio de fazer a denúncia e/ou de procurar um serviço de defesa de seus direitos, pois não se sentiam bem tratadas e tinham vergonha, pois na maioria das vezes não era a primeira vez que procuravam algum tipo de “ajuda” do Estado para resolver a situação de violência vivida. Sinalizando a ocorrência nessas situações do que Faleiros e Faleiros (2007) denominam de violência institucional, que se instaura nas mais diferentes instituições, programas e serviços.

Essas constatações fizeram com que, no projeto se definisse por realizar a investigação sobre os referidos serviços, tendo por referência o conhecimento e a opinião

\footnotetext{
${ }^{1}$ O NUPS deu lugar à Secretaria Psicossocial Judiciária - SEPSI no ano de 2007. E as atividades desenvolvidas pelo Núcleo foram divididas em duas frentes de trabalho, sendo que os casos de violência ficaram sob a responsabilidade do Serviço de Atendimento às Famílias em Situação de Violência - SERAV do Tribunal de Justiça do Distrito Federal e Territórios - TJDFT. Motivo pelo qual utilizamos nesse trabalho a sigla conjugada de ambos os serviços para referir-nos ao setor.
} 
das mulheres envolvidas em situações de violência conjugal, atendidas pelo Núcleo Psicossocial Forense - NUPS, atualmente denominado de Serviço de Atendimento às Famílias em Situação de Violência - SERAV, e cujos processos já houvessem sido encerrados e os respectivos relatórios encaminhados para a juíza responsável pelo caso. Pretendia-se assim focar o estudo em situações cujo ciclo de intervenção do NUPS/SERAV já houvesse se encerrado.

Entretanto, dificuldades de acesso às mulheres em questão ${ }^{2}$ requereram a realização de ajustes, de modo a não abandonar o objetivo de conhecer, refletir e sistematizar informações sobre o funcionamento dos serviços que atendem as mulheres vítimas de violência conjugal.

Devido à relevância e também facilidade de acesso, optamos por realizar a investigação sobre os serviços a partir da ótica da equipe técnica da SERAV, responsável pelo atendimento das mulheres envolvidas em processos relacionados à violência conjugal. Assim, embora o foco da monografia tenha sido redirecionado no sentido de contemplar a perspectiva dos técnicos, e não mais das mulheres, a reflexão e conhecimento em torno das características de constituição de uma possível rede destinada a coibir e prevenir a violência doméstica e familiar contra a mulher no DF, prevista na Lei 11.340/2006, permaneceu como questão central (BRASIL, 2006).

O recorte temporal da pesquisa, de novembro de 2006 a janeiro de 2007, se deveuse ao fato de no mesmo estarem inseridos os casos que tiveram o acompanhamento no SERAV encerrados, o que possibilitou uma melhor análise das pastas. Estes casos representam os casos inaugurais da Vara do Juizado de Violência Doméstica e Familiar contra a Mulher de Brasília, sendo que este juizado foi criado após uma estipulação contida na Lei “Maria da Penha” e será detalhadamente explicado adiante neste trabalho.

\footnotetext{
2 Consultados a respeito, integrantes da equipe técnica do NUPS/SERAV revelaram enfrentar grande dificuldade para entrarem em contato com estas mulheres, após o envio do processo ao Juiz, para a realização do "Follow-up" dos casos atendidos (segundo um dos técnicos, de 20 mulheres convocadas para a entrevista de retorno do caso, apenas uma compareceu).
} 


\subsection{Instrumentos de coleta de dados}

Após a reorientação da proposta de pesquisa, a realização do trabalho de campo foi materializada por meio de análise documental das pastas de acompanhamento individual/familiar das mulheres vítimas de violência conjugal, existente no NUPS/SERAV, para tal foi elaborado um instrumental específico para coleta dos dados. Também foi elaborado um instrumental e realizada uma entrevista semi-estuturada com integrantes da equipe técnica.

Antes, porém, precedeu-se ao levantamento bibliográfico de obras referente à temática da violência, da violência contra a mulher, sobre a Lei 11.340/2006, conhecida como Lei “Maria da Penha” e também relacionado ao conceito de rede. Este levantamento foi necessário para subsidiar a construção do objeto e para delimitação do problema, da pergunta e da hipótese da monografia.

Concomitante ao levantamento e leitura da bibliografia se realizou a observação participante no Grupo de Acolhimento e Pré - Audiência das mulheres vítimas de violência conjugal na Vara do Juizado de Violência Doméstica e Familiar contra a Mulher de Brasília no TJDFT, durante os meses de abril e maio de 2007. Essa participação permitiu a elaboração de diário de campo, com a anotação de informações sobre metodologia do grupo e falas de mulheres neste, que consistiram subsídios importantes na elaboração do projeto da monografia.

Definida a utilização de entrevistas semi-estruturados com roteiro e a utilização das pasta de acompanhamento individual/familiar das mulheres atendidas existentes no NUPS/SERAV, o momento seguinte foi destinado à elaboração dos instrumentais de coleta de dados, que resultou em dois questionários e em um termo de consentimento.

O primeiro questionário foi direcionado para conhecer a o perfil socioeconômico e cultural das mulheres vítimas de violência conjugal e para realizar um levantamento de quais foram os técnicos que atenderam os casos encaminhados para o serviço no período de novembro de 2006 e janeiro de 2007 (Vide Anexo I). As perguntas abertas que seriam realizadas com as mulheres foram suprimidas e o questionário foi formatado para perguntas fechadas de múltipla escolha, com base na análise previamente realizada, tanto nos 
instrumental do SERAV contido nas pastas quanto nas anotações dos técnicos nas pastas realizadas no decorrer do acompanhamento.

Ainda nesse momento, foi elaborado o segundo questionário para ser aplicado aos técnicos do SERAV, e também foi estruturado um termo de livre consentimento (Vide Anexo II e III). O questionário dos técnicos foi pautado em duas partes: a primeira destinase a conhecer acadêmica, social e profissionalmente os técnicos, e o segundo a conhecer os procedimentos internos do SERAV para acompanhamento dos casos, assim como o encaminhamento para outros serviços e análise e retorno destes para a justiça. Desta forma reiteramos que não houve a possibilidade de analisar cada serviço isoladamente, como seria feito no caso de uma pesquisa realizada com as próprias mulheres vítimas de violência conjugal.

Com o objetivo de realizar as entrevistas com os técnicos do SERAV, foi construído também um termo de consentimento específico. Tal termo visa garantir a ética na pesquisa e evitar futuros constrangimentos. Além do termo de consentimento ser um documento que resguarda tanto a pesquisadora quanto o entrevistado.

\subsection{A realização da pesquisa de campo}

O momento destinado à coleta dos dados foi dividido em duas etapas. A primeira destinou-se a aplicação do primeiro questionário (Vide Anexo I) visando à análise dos dados das pastas. Por meio deste instrumental foram coletados os dados nas pastas de acompanhamento individual/familiar dos casos encerrados, que se encontram em um arquivo próprio no NUPS/SERAV. A segunda etapa foi destinada à realização de entrevistas com integrantes da equipe técnica (Modelo Vide Anexo III).

A amostra da quantidade de entrevistas que deveriam ser realizadas com os técnicos foi definida após a tabulação dos dados das pastas, pois a partir destas pôde-se conhecer quais eram os técnicos que mais realizaram o acompanhamento dos respectivos casos do serviço.

Vale ressaltar que as informações obtidas por intermédio da consulta às pastas de acompanhamento individual, assim como das entrevistas são confidenciais, e para tal foi 
assegurado o total sigilo das 18 perguntas respondidas pelos/as técnicos/as, pois apesar das respostas serem anotadas e gravadas, logo após a análise foram descartadas.

Os dados das referidas entrevistas não serão divulgados de forma a possibilitar a identificação dos (as) entrevistados (as) e nem das mulheres vítimas de violência doméstica e familiar, e para tanto foi adotada uma codificação que somente a pesquisadora poderá identificar posteriormente as pessoas entrevistadas.

Após a coleta procedeu-se à tabulação dos dados obtidos na consulta às pastas das mulheres vítimas de violência e à transcrição e leitura, em profundidade, das entrevistas. Pois, desta maneira foram analisados os dados levantados e efetivada a comparação com a hipótese do projeto.

No próximo capítulo será apresentada uma tentativa de aproximação conceitual do termo violência, e as suas manifestações na sociedade. Particularmente este capítulo debaterá a violência conjugal e as implicações da questão de gênero em vários espaços, tais questões consistem na base teórica para o desenvolvimento desta monografia. 


\section{Capítulo 2 - Violência: aproximação conceitual}

A violência é conceituada de modos diversos no debate científico e acadêmico. Cada um dos autores que discute esta temática enfatiza, em sua perspectiva, determinado aspecto deste fenômeno. Estas diferentes perspectivas se devem ao fato da violência estar inserida em diferentes contextos da sociedade, como afirma Lourdes Bandeira e Mireya Suárez (1999), e também por esta assumir os mais variados significados tanto para a pessoa que a "exerce" quanto para a pessoa que a "sofre".

Para José Vicente Tavares dos Santos (1999) a violência é difusa, está presente em toda a sociedade e atinge diferentes grupos sociais, o que significa que a violência pode acontecer independente da classe social, da raça, etnia e faixa etária.

Já Pierre Bourdieu (2005) explora a dimensão simbólica da violência. Para ele, essa acontece por intermédio de um poder simbólico e muitas vezes acontece de maneira sutil. Tal "sutileza" da violência nem sempre é percebida, e em determinados casos é naturalizada e legitimada tanto pelo indivíduo, quanto pelo grupo ou a sociedade em que vive.

A restauração ou manutenção de um determinado poder também pode ser associada ao fenômeno da violência. No texto: Violência, reciprocidade e desigualdade: uma perspectiva antropológica, Gilberto Velho analisa a estreita relação entre violência e poder. Segundo o autor, os pilares do poder são à base da violência, que se efetiva quando os recursos para a resolução de determinados conflitos são escassos ou inexistentes.

As peculiaridades de cada uma dessas concepções não obscurecem pontos de contato entre as idéias abordadas pelos três autores: tanto em Santos (1999) como em Bourdieu (2005) e Velho (1996), está presente a idéia da violência associada à idéia de poder. Este poder, conforme Bourdieu (1999), pode ser exercitado de diferentes maneiras, mesmo contra a vontade do outro e geralmente está intimamente relacionado à questão da dominação, mesmo que seja uma dominação simbólica.

O objetivo central deste capítulo é realizar uma aproximação conceitual do tema e para tanto são abordadas as múltiplas dimensões da violência e os variados contextos em que se faz presente, com atenção especial à violência na conjugalidade. 


\subsection{A violência: um fenômeno de múltiplas dimensões.}

A violência apresenta-se enraizada em todas as camadas da sociedade e pode acontecer a qualquer momento e em qualquer ocasião. Cada indivíduo é capaz de exemplificar, segundo sua própria concepção, pelo menos uma forma de violência, independente de sua classe social, faixa etária, raça, etnia e gênero (SANTOS, 1999).

Em seu texto: Por uma sociologia da conflitualidade no tempo da globalização, José Vicente Tavares dos Santos (1999) denomina de 'globalização da violência' o fato da violência está inserida em todos os segmentos da sociedade. O autor também enfatiza que este fato dilacera a cidadania de maneira contundente e a cada momento.

No mundo globalizado, onde todos os fatos estão intimamente interligados, a violência assume posição de destaque nos debates acadêmicos, políticos e sociais. Isso se deve às proporções que alcança, fazendo-se presente em todos os segmentos (SANTOS, 1999).

A complexificação das questões sociais segundo Santos (1999), deve-se às inúmeras dimensões do social que passam a ser questionadas. Tais questionamentos referem-se, principalmente, a atual forma de organização da sociedade, na qual fica evidente a desigual distribuição dos recursos econômicos e a crescente miséria da população.

O processo de 'globalização da violência’ está em curso desde o surgimento do modo de produção capitalista. A relação entre a exploração e a dominação se estabelece nos campos sociais, políticos e econômicos das sociedades industriais, geralmente por intermédio da violência simbólica (SANTOS, 1999).

Gilberto Velho (1996) assinala que a complexidade de questões sociais existentes na sociedade gera diferenças que geram ainda mais diferenças, em um processo contínuo e dialético. "Uma das diferenças associadas diretamente à produção de tensão e conflito é a desigualdade social. A possibilidade de legitimá-la ideologicamente está ligada à existência de universos simbólicos mais ou menos abrangentes” (VELHO, 1996, p.13).

Para Saul (apud SANTOS, 1999) a violência está relacionada à miséria, ao processo de modernização, aos altos índices econômicos e a precarização do emprego. Para o autor existe: 
(...) relação estreita entre miséria e violência uma vez que a extensão da pobreza e da miséria é resultante de um processo de modernização que combina altos índices econômicos com elevados índices de marginalização de indivíduos da atividade produtiva organizada, com a conseqüente precarização do emprego como elemento central da reorganização econômica (SAUL, apud SANTOS, 1999, p. 24 e 25).

Para os autores abordados acima, a violência não se limita apenas ao uso da força física propriamente dita, embora a possibilidade de usá-la esteja sempre presente. Tampouco se pode afirmar que há um grupo de pessoas que podemos considerar como “pré-determinado" tanto para o exercício quanto para o recebimento de atos de violência, embora haja circunstâncias e contextos específicos que podem favorecer ou restringir a ocorrência dessa.

Para Velho (1996), a idéia de poder põe em cena a imposição de uma determinada vontade:

Violência não se limita ao uso da força física, mas a possibilidade ou ameaça de usá-la constitui dimensão fundamental de sua natureza. Vê-se que, de início, associa-se a uma idéia de poder, quando se enfatiza a possibilidade de imposição de vontade, desejo ou projeto de um ator sobre o outro. (VELHO, 1996, p. 10).

Na mesma direção, Soares (1999) afirma ser muito limitado definir a violência somente em termos dos aspectos relacionados às sensações de dor e sofrimento físico, haja visto que exclui aspectos importantes da violência, como a dimensão emocional, a violência verbal, a ameaça e os abusos sexuais, por exemplo.

Para Bourdieu (2005) a imposição da vontade se associa à questão da dominação. É com base no entendimento da relação entre os conceitos de dominação e poder simbólico que Pierre Bourdieu propõe e desenvolve o conceito de violência simbólica em seus livros Dominação Masculina (1999) e O Poder Simbólico (2005). Segundo o autor, a violência simbólica não é exercida apenas pela força física, mas por intermédio de um poder camuflado e disfarçado e que muitas vezes não é percebido.

Entre as relações em que a violência simbólica pode ser estabelecida, incluem-se os relacionamentos diretos e os indiretos, ou seja, a violência pode ocorrer tanto no espaço privado da família (discussão entre pai e filho, imposição de regras e limites na relação conjugal), quanto em espaços públicos da sociedade (ambiente de trabalho, em atendimento no hospital ou em uma fila para recebimento de um benefício social). Assim a violência 
pode se fazer presente em várias formas de relacionamento e em diferentes contextos, podendo ser legitimada por um poder simbólico, que se apresenta difuso (espalhado, enraizado) na sociedade (SANTOS, 1999).

A questão da dominação masculina analisada por Bourdieu (1999), tendo em perspectiva a relação conjugal, está relacionada à violência simbólica:

Também sempre vi na dominação masculina, e no modo como é imposta e vivenciada, o exemplo por excelência desta submissão paradoxal, resultante daquilo que eu chamo de violência simbólica, violência suave, insensível, invisível as suas próprias vítimas, que se exerce essencialmente pelas vias puramente simbólicas da comunicação e do conhecimento, ou, mais precisamente, do desconhecimento, do reconhecimento ou, em última instância, do sentimento. (BORDIEU, 1999, p. 7-8).

Bourdieu (1999) afirma que a violência masculina está enraizada socialmente por meio da reprodução do processo histórico, envolvendo homens, mulheres, famílias, escolas, igrejas, hospitais, Estado. Também está presente em nosso inconsciente, impregnada no corpo e na alma e muitas vezes além de ser imperceptível ainda é legitimada por nós.

Para o autor citado acima, o sistema simbólico é na verdade uma construção que está presente em uma cultura e a manutenção deste torna-se fundamental para a perpetuação da violência simbólica, uma vez que este sistema simbólico é centrado na construção da inferioridade e na naturalização da dominação e da violência, sendo desenvolvido por intermédio de um poder disfarçado e camuflado.

Bourdieu (1999) enfatiza que o poder simbólico pode acontecer com a exacerbação da dominação, intermediada pela imposição de uma cultura e/ou religião sobre outra. Pode estar associado, também, ao domínio de uma classe social sobre outra, por meio de relações de opressão e subordinação. Desta maneira, a estruturação da violência simbólica se relaciona, segundo o autor, com as formas de imposição da cultura dominante sobre uma determinada cultura dominada:

A cultura dominante contribui para a integração real da classe dominante (assegurando uma comunicação imediata entre todos os seus membros e distiguindo-os das outras classes); para a integração fictícia da sociedade no seu conjunto, portanto, à desmobilização (falsa consciência) das classes dominadas; para legitimação da ordem estabelecida por meio de estabelecimento das distinções (hierarquias) e para a legitimação destas distinções. Este efeito ideológico, produto a cultura dominante 
dissimulando a função de divisão na função de comunicação: a cultura que une (intermediário de comunicação) é também a cultura que separa (instrumento de distinção) e que legitima as distinções compelindo todas as culturas (designadas como subculturas) a definirem-se pela sua distância em relação à cultura dominante (BOURDIEU, 2005, p. 10 e 11).

Essa idéia de dominação simbólica formulada por Bourdieu (1999 e 2005) converge com o conceito de violência estrutural apresentado por Minayo (1993) no texto A violência social sob a perspectiva da saúde pública. De acordo com a autora, a violência estrutural é expressão das desigualdades e se trata de uma violência cumulativa e excludente que está presente em todos os níveis sociais, podendo ser exercida pelo próprio Estado por meio de suas políticas públicas não comprometidas.

A violência estrutural está, pois intimamente ligada à dominação simbólica, uma vez que a cultura de dominação de um segmento sobre o outro (ou de um grupo sobre outro, na relação de dominantes sobre dominados) também está presente nesta forma de violência.

A questão da violência institucional é abordada por Faleiros e Faleiros (2007), que destacam as noções de dominação e da violência simbólica formuladas por Bourdieu (1999 e 2005). De acordo com os autores, a violência institucional possui uma dimensão simbólica que pode se revelar nos mais variados contextos, por intermédio de símbolos e de uma violência camuflada e suave, que muitas vezes nem os atores e nem as vítimas percebem a ocorrência desta.

Segundo Faleiros e Faleiros (2007) a violência institucional pode se materializar das mais diferentes maneiras (psicológica, moral, física, patrimonial e/ou sexual) e está associada aos locais onde se faz presente, como por exemplo: delegacias, instituições de saúde, abrigos, hospitais, tribunais e escolas. Assim:

A violência institucional, que se manifesta de diferentes formas (física, psicológica, e/ou sexual), se caracteriza por estar associada às condições específicas dos locais onde ocorre, como instituições de saúde, escolas, abrigos. As condições materiais das instituições também são exemplares da violência estrutural. A carência de pessoal e de equipamentos, as filas de espera, a falta de material, os horários inadequados de atendimento, a ausência de profissionais no trabalho e outras questões que conduzem ao não atendimento, ao atendimento precário e ao desrespeito dos direitos dos usuários são manifestações desse tipo de violência (FALEIROS; FALEIROS, 2007, p. 31). 
Desta maneira podemos compreender que a violência pode ocorrer em diferentes contextos e que até nas instituições ela se faz presente. Em muitas situações nem os profissionais percebem que estão perpetuando a violência e terminam por fazer uso da “negligência profissional” nos atendimentos realizados (FALEIROS; FALEIROS, 2007). Esta negligência pode estar associada muitas vezes à falta de incentivo e de capacitação dos profissionais destes serviços.

A violência institucional e as outras abordadas no decorrer deste capítulo podem ser perpetradas contra a mulher vítima de violência doméstica e familiar. Desta forma, além de sofrer violência no contexto privado (família), a mulher ainda sofre outras violências por parte da "sociedade", nos serviços que seriam responsáveis por realizar sua defesa. No próximo item serão apresentados os conceitos referentes à violência perpetrada contra a mulher na conjugalidade.

\subsection{A violência na conjugalidade na perspectiva de gênero}

A violência que atinge mulheres em suas relações de conjugalidade, que aqui se denomina violência conjugal, será analisada neste item a partir do exame três conceitos que lhe são próximos. O primeiro refere-se à violência doméstica; o segundo a violência familiar e o último à violência de gênero e suas especificidades.

A escolha por definir a violência conjugal na perspectiva destes três conceitos se

deve ao fato da mesma não possuir, no debate científico a acadêmico, um conceito central e ser compreendida de múltiplas formas.

Antes de iniciar uma análise dos conceitos de violência conjugal cabe destacar o conceito defendido por Diehl (2002), referente ao termo conjugalidade, pois este é extremamente relevante para a construção deste trabalho. Para o autor o termo conjugalidade é um neologismo e deriva da palavra conjugar que significa a ligação e união estabelecida entre duas pessoas, sem necessidade de haver um vínculo ou contrato formal estabelecido entre estas (casamento civil), sendo que geralmente estas pessoas convivem no mesmo espaço doméstico.

Desta forma, podemos compreender a definição apresentada pela autora Fernanda Marques de Queiroz (2002), uma vez que esta define os termos violência conjugal e 
violência doméstica como conceitos semelhantes, e enfatiza que neste tipo de violência o agressor possui relações de afetividade com a vítima:

A violência exercida contra as mulheres, também denominada de violência conjugal ou doméstica, se constitui num fenômeno que atinge mulheres de todas as partes do mundo. Em geral é praticada na esfera privada e o agressor mantém laços de afetividade com a vítima, tornandoa mais vulnerável a essas práticas, pois estão em jogo, sentimentos de afeto, cumplicidade etc. $\mathrm{O}$ fato dessa violência ocorrer freqüentemente no âmbito doméstico e ser praticada por pessoas com as quais as vítimas mantêm relações afetivas não lhe retira o caráter político e, portanto, público, devendo, portanto, ser denunciada e repudiada por todos(as) nós(...) (QUEIROZ, 2002, p.30).

Já outros autores estabelecem semelhanças entre os conceitos de violência doméstica e familiar (intrafamiliar) e não fazem nenhuma distinção entre os mesmos, como se pode observar na afirmação de Patrícia da Conceição Santos na sua monografia intitulada de Violência contra a Mulher no DF: causas e dimensões (2001, p. 12):

Uma das faces apresentadas pela violência é chamada de violência doméstica ou intrafamiliar, que ocorre no âmbito das relações particulares entre integrantes ou ex-integrantes de uma mesma família, tendo normalmente a casa como espaço físico de sua manifestação.

A respeito da família, Santos (2001) destaca que as sociedades, de modo geral, atribuam à família lugar central,

(...) para a continuação da existência da vida social, já que a mesma é considerada como núcleo de toda a sociedade. No entanto, isso não significa afirmar que essa instituição tenha se organizado observando todos os princípios fundamentais de respeito à pessoa humana, pois a mesma tem sido espaço de hierarquia e subordinação e de graves casos de violência. (SANTOS, 2001, p. 12).

Cavalcanti (2007) destaca que a violência doméstica pode ser perpetrada contra mulheres, crianças, homens e idosos no espaço 'doméstico'. O conceito de Cavalcanti (2007) destaca o fato violência doméstica ocorrer no espaço físico da casa, sem se limitar ao "âmbito das relações particulares entre integrantes ou ex-integrantes de uma mesma família”, como entendido por Santos (2001).

O espaço de convívio "permanente das pessoas" citado por Cavalcanti (2007) não significa necessariamente o espaço físico da casa, pois esta violência também pode acontecer em outros contextos. A concepção de família adotada é bastante ampla, 
não se refere apenas aos laços consangüíneos, mas também aos vínculos sociais e culturais que foram construídos.

Para Cavalcanti (2007), a violência doméstica independe de classe social, religião, etnia, grau de escolaridade e condição financeira, tanto da pessoa que a sofre quanto da pessoa que a realiza. Há que se destacar que, em se tratando de violência doméstica contra a mulher, o agressor, geralmente, é uma pessoa que utiliza de uma “condição privilegiada de uma relação de casamento, convívio, confiança, amizade, namoro, intimidade, privacidade que tenha ou tenha tido com a vítima, bem como da relação de hierarquia ou poder que detenha sobre a vítima para praticar a violência” (CAVALCANTI, 2007, p. 49).

Nessa perspectiva, a violência doméstica pode ser praticada por pessoas que não necessariamente são da mesma família, como acontece na violência de babás contra criança no espaço doméstico, na violência de um amigo contra a amiga na casa dela ou na autoridade exacerbada de um membro que não pertence diretamente a uma família, mas que possui influência sobre esta.

A violência doméstica e familiar contra a mulher é uma das principais causas de morte do sexo feminino no país, segundo dados do BID - Banco Internacional de Desenvolvimento. Acredita-se que 70\% dos crimes contra as mulheres são executados na própria casa, sendo o agressor uma pessoa com quem esta mantém relação afetiva, geralmente o companheiro ou marido.

Em pesquisa realizada em 2001 pela Fundação Perseu Abramo, constatou-se que no Brasil são espancadas mais de 2 (dois) milhões de mulheres no contexto doméstico e familiar em um ano, 175 mil em um mês, mais de 5 mil mulheres por dia. Ainda segundo a pesquisa, a cada 15 (quinze) segundos uma mulher é vítima de violência no país, completando uma média de 4 (quatro) mulheres espancadas a cada minuto.

Vários estudos têm enfatizado que a violência contra a mulher tem como um de seus pilares centrais a desigualdade entre os gêneros, ou seja, os aspectos sociais, culturais e emocionais que organizam e legitimam socialmente a hierarquização das diferenças entre os homens e as mulheres. 
Muitas vezes a violência de gênero é propagada por uma forma simbólica, em que as regras e os códigos são sutis, que nem sempre são percebidos de forma clara, e em muitas situações são legitimados e repassados ao longo da história (Bourdieu, 2005).

Faleiros e Faleiros (2001) assinalam que a violência contra a mulher se baseia em uma relação de desigualdade e poder estabelecida. Nessa forma de relação se exercita a força, e esta pode ser considerada legitima ou não, na manutenção ou resistência da dominação. O agressor nessas situações não é, geralmente, um desconhecido, mas alguém bem próximo à vítima.

Analisando as discussões e formulações conceituais relativas aos fenômenos da violência contra a mulher, destaca-se os pressupostos formulados por Heleieth. I. B. Saffioti (2001), no texto Contribuições feministas para o estudo de violência de gênero. Neste texto a autora enfatiza que a captação e análise do conceito de gênero representa um ponto crucial para a compreensão das várias desigualdades entre homens e mulheres.

O conceito de gênero é utilizado em uma gama bem variada de contextos. Inicialmente este termo surgiu como uma oposição dos termos sexo e diferença sexual. Esses dois conceitos citados anteriormente enfatizavam as diferenças centradas nos aspectos biológicos dos homens e das mulheres (SCOTT, 1995).

No artigo Das origens da desigualdade de gênero, as autoras Anne-Marie Pessis e Gabriela Martín (2000) explicam que o conceito de sexo é marcado por um “determinismo biológico” defendido por algumas teorias. Tais teorias defendem que de fato existem diferenças determinadas pelo sexo e que isto justifica o fato das mulheres possuírem um desenvolvimento da racionalidade inferior a dos homens. Estas diferenças nos papéis sociais destinados aos homens e as mulheres foram construídas e legitimadas ao longo da história e são, portanto, oriundas das relações de poder concebidas por intermédio das concepções patriarcais (GÖSSMANN, 1996).

Ainda hoje é comum escutar muitas expressões ligadas aos papéis sociais tanto dos homens quanto das mulheres e que podemos relacionar ao conceito do "determinismo biológico: “O homem deve trabalhar fora e a mulher deve cuidar dos filhos”, “a mulher deve respeitar todas as decisões do seu marido”, “o homem é forte e a mulher é fraca”, “a mulher é sensível”, “homem não pode chorar”; além de muitas outras na sociedade. 
E estes papéis sociais não se expressam somente na vida adulta, eles são ensinados para as crianças desde a infância e muitas vezes as 'manifestações' de tais papéis acabam ocorrendo de maneira exacerbada, com atos de violência.

Os papéis ensinados desde a infância fazem com que meninos e meninas aprendam a lidar com a emoção de maneira diversa. Os meninos são ensinados a reprimir as manifestações de algumas formas de emoção, como amor, afeto e amizade, e estimulados a exprimir outras, como raiva, agressividade e ciúme. Essas manifestações são tão aceitas que muitas vezes acabam representando uma licença para atos violentos (CAVALCANTI, 2007, p. 54).

No sistema patriarcal a valorização do masculino acontece a todo o momento em detrimento do feminino. O patriarcado, segundo Gössmann (1996, p.369): “Abrange tanto as formas de organização social pré-estatais como as ‘sociedades segmentárias””, e a subordinação da mulher ao homem acontece nos espaços judiciários, institucionais e de poder político que são os espaços extrafamiliares, onde também são realizadas e legitimadas as inúmeras formas de domínio.

A formulação do conceito gênero destaca a necessidade de considerar a presença de aspectos psicológicos, sociais e culturais na construção da feminilidade e da masculinidade (SCOTT, 1995).

Esse conceito foi construído ao longo da história contemporânea e o feminismo ocupa um papel primordial nesse processo. Joan Scott (1995) chama a atenção para o fato de o termo gênero, muitas vezes, ser utilizado como sinônimo de “mulheres” e a importância das publicações de artigos e livros sobre a temática que enfatizam somente a história da mulher. A autora acredita que este é um dos aspectos utilizados pelas feministas no espaço acadêmico e que tem como objetivo alcançar a legitimidade em suas publicações e em seus estudos, tal fato pode ser percebido com clareza na década de 1980.

Para a autora citada anteriormente “... as feministas começaram a utilizar a palavra 'gênero' mais seriamente, no sentido mais literal, como uma maneira de referir-se à organização social da relação entre os sexos” (SCOTT, 1995, p.1).

Entre as várias abordagens de gênero pelos (as) historiadores (as) feministas, Scott (1995) considera que:

Os (as) historiadores (as) feministas utilizaram toda uma série de abordagens na análise de gênero, mas estas podem ser resumidas em três posições teóricas. A primeira, um esforço inteiramente feminista que tenta 
explicar as origens do patriarcado. A segunda se situa no seio de uma tradição marxista e procura um compromisso com as críticas feministas. A terceira, fundamentalmente dividida entre o pós-estruturalismo francês e as teorias anglo-americanas das relações de objeto, inspira-se nas várias escolas de psicanálise para explicar a produção e a reprodução da desigualdade de gênero do sujeito (SCOTT, 1995, p. 4).

Outros autores consideram que os grupos feministas entre os seus vários segmentos e dissidências possuem concepções diferentes sobre a definição do conceito de gênero. A afirmação anterior vai ao encontro com o debate realizado por Saffioti (2001). A citação a seguir ilustra a posição e análise da autora sobre tal situação:

A perspectiva feminista toma o gênero como categoria histórica, portanto subjetiva, e também como categoria analítica, por conseguinte, adjetiva. Não existe um modelo de análise feminista. Rigorosamente o único consenso existente sobre o conceito de gênero reside no fato de que se trata de uma modelagem social, estaticamente, mas não necessariamente, referida ao sexo. Vale ressaltar que o consenso, entretanto, termina aí. Feministas há que ainda trabalham com o conceito de sexo/gênero, outras que se apegam às diferenças sexuais para explicar o gênero, resvalando, às vezes, pelo essencialismo biológico, e outras, ainda, afirmam de tal modo o primado do social que acabam por negar ou, pelo menos, a ignorar o corpo, abraçando o essencialismo social (SAFFIOTI, 1997, p.8).

Assim, com a compreensão de que o conceito de gênero é amplo e que o mesmo não se refere apenas às diferenças biológicas entre homens e mulheres, Saffioti (2001) propõe a adoção do conceito de violência de gênero para explicar não somente a violência doméstica e familiar sofrida pela mulher, mas por entender que este abarca outras formas de violência.

Para Saffioti (2001, p. 1-2):

Violência de gênero é o conceito mais amplo, abrangendo vítimas como as mulheres, crianças e adolescentes de ambos os sexos. No exercício da função patriarcal, os homens detêm o poder de determinar a conduta das categorias sociais nomeadas, recebendo autorização ou, pelo menos, tolerância da sociedade para punir o que se lhes apresenta como desvio. Ainda que não haja nenhuma tentativa, por parte das vítimas potenciais, de trilhar caminhos diversos do prescrito pelas normas sociais, a execução do projeto de dominação-exploração da categoria social homens exige que sua capacidade de mando seja auxiliada pela violência. Com efeito, a ideologia de gênero é insuficiente para garantir a obediência das vítimas potenciais aos ditames do patriarca, tendo este necessidade de fazer uso da violência. 
Uma vez debatido os três conceitos principais de violência contra a mulher: violência doméstica, violência familiar (ou intrafamiliar) e violência de gênero; podemos estabelecer uma pergunta-chave: O que leva as mulheres vítimas de violência conjugal a se manterem em um relacionamento violento?

Em primeiro lugar, na tentativa de responder a pergunta realizada, iniciaremos com o que é defendido por Bourdieu (2005). Para o autor a violência contra a mulher é estruturada sob a perspectiva da dominação simbólica. E esta forma de dominação pode ser uma das questões que levam a mulher vítima de violência a se manter em um relacionamento agressivo.

A violência simbólica ou mesmo a cultura podem ser concebidas como arbitrárias, por se assentarem em determinados preconceitos, além de poderem ser compreendidas também como uma verdadeira construção da inferioridade (BOURDIEU, 2005).

Outra possível resposta, que pode correlacionar-se com a primeira, é o fato da conjugalidade possuir em seu seio uma idéia de contrato “pré-estabelecido”, onde são determinados os direitos e deveres, tanto individuais quanto aqueles pertencentes ao casal. Esta questão do ‘contrato’ da conjugalidade é defendida por Machado e Magalhães (1999). Para as autoras a conjugalidade é “fortemente enraizada na idéia de contrato”, e este contrato social na conjugalidade também “incide sobre a sexualidade e a fidelidade da mulher” (MACHADO; MAGALHÃES, 1999, p. 196).

Uma terceira resposta possível refere-se à concepção do significado cultural, social, político, institucional e econômico da família, pois a família é uma instituição e seu espaço e poder são legitimados social e culturalmente. Vale ressaltar que tal instituição é regida por inúmeros “contratos”.

No livro Violência contra a mulher: Quem mete a colher, a autora Marlise Vinagre Silva (1992) considera a família como um 'local privilegiado’. A seguir está expressa a definição da autora:

A família é um locus privilegiado, onde se inscrevem relações contraditórias travejadas pelo autoritarismo e pela afetividade. Neste cenário têm lugar situações de conflito, fundadas em relações de micropoder de natureza antagônica manifestadas de forma mais ou menos explicita. Emoldurados nos contornos das relações de poder da família (no 
ambiente doméstico), encontra-se o fenômeno de violência conjugal, onde o alvo freqüente é a mulher (SILVA, 1992, p. 48).

Ainda com o objetivo de responder a pergunta realizada, e como complemento da resposta anterior, pode-se considerar que a família possui suas ações legitimadas pelo Estado. A citação de Suárez (apud FREITAS, 1998) analisa a relação entre Estado e família:

A família é, e sempre foi uma instituição privada que o Estado tem deixado relativamente irrestringível. O pressuposto de não intervenção do Estado não apenas tem aprovado a autonomia patriarcal da família e desse modo tolerado a violência masculina, mas tem colocado a violência contra as esposas em maus lençóis... Isto, e muito mais tem contribuído para a emergência de uma perspectiva laissez-faire com relação à violência doméstica, da qual o Estado tem sido visto intervir somente em ultimo recurso (SUÁREZ, apud FREITAS, 1998, p. 17).

No artigo Explorando significados do silêncio e do segredo nos contextos de violência doméstica, Gláucia Diniz e Miriam Pondaag afirmam que as mulheres se consideram mantenedoras e responsáveis pelos "vínculos familiares, cuidadoras das relações, como protetoras, e como salvadoras. Por outro lado, elas se vêem como mulheres e mães culpadas, responsáveis pelos fracassos familiares” (DINIZ; PONDAAG, 2004, p.176).

Portanto, além da não intervenção do Estado nas questões relacionadas à família, compreende-se que a construção social e cultural da feminilidade e da masculinidade tem forte relação com as interpretações das mulheres acerca da sua própria função e importância na família (DINIZ; PONDAAG, 2004).

No próximo capítulo será apresentada a relação existente entre os movimentos feministas e a constituição de políticas públicas para as mulheres. O objetivo central é conhecer a trajetória histórica e social para a elaboração da lei que visa coibir as formas de violência doméstica e familiar contra a mulher. 


\section{Capítulo 3 - O Movimento Feminista e a Construção de Políticas Públicas para as Mulheres}

O movimento feminista desempenhou e desempenha no Brasil, papel central na luta contra a violência contra a mulher e na constituição de políticas públicas voltadas ao enfrentamento das desigualdades fundadas no gênero. Dentre as conquistas mais recentes nesse campo destacam-se a construção do Plano Nacional de Políticas para as Mulheres PNPM e a promulgação da Lei 11.340/2006, conhecida como Lei Maria da Penha.

Este capítulo tem por objetivo, num primeiro momento, caracterizar e contextualizar historicamente o movimento feminista para depois então, analisar a relação deste com o processo de formulação e implantação de políticas voltadas ao enfrentamento das desigualdades de gênero e mais particularmente com a lei “Maria da Penha”.

Deve-se salientar que tal capítulo não possui a pretensão de analisar profundamente cada conquista do movimento feminista de maneira isolada, mas sim realizar um apanhado geral de questões centrais desse movimento no cenário mundial, mais precisamente no que tange as ações de tal movimento na América Latina e Caribe. E também sobre o surgimento e desenvolvimento do movimento feminista no Brasil.

A autora Céli Regina Jardim Pinto no seu livro Uma história do feminismo no Brasil afirma que “(...) é uma tarefa peculiar escrever sobre o movimento pela forma que se organizou: tem sido por natureza um movimento fragmentado, com múltiplas manifestações, objetivos e pretensões diversas” (PINTO, 2003, p. 9).

Desta forma, com base na citação acima, reiteramos a questão sobre o objetivo principal desse capítulo, não sendo, portanto o de aprofundar em muitos pontos relacionados ao feminismo, mas sim realizar um apanhado geral dos principais fatos e enfatizar as mudanças em termos de estratégia ocorrida no interior do movimento feminista.

\subsection{Caracterização e contextualização histórica do Movimento Feminista}

O feminismo teve e ainda tem diferentes pautas e objetivos ao longo do tempo, esse movimento não é um fenômeno das “sociedades” em geral, mas é muito próprio do mundo ocidental, tendo surgido inicialmente nos países da Europa e depois Estados Unidos. 
Mas não podemos determinar com exata precisão quando surgiram os primeiros grupos ou o movimento feminista, tanto em nível mundial quanto no Brasil. Isso não nos impede de contextualizar o surgimento do movimento, a partir de marcos históricos que enfatizam a estruturação e consolidação deste.

As mulheres lutaram para serem reconhecidas como cidadãs em suas sociedades, e para não serem apenas, meros "apêndices” do universo masculino. Universo em que permaneciam em quase absoluto silêncio e que eram delegadas a elas, apenas as "funções” sem nenhum valor. Mas a primeira ou mais significativa luta das mulheres brasileiras foi relacionada ao direito de votarem. (PINTO, 2003, p. 10). A primeira fase do movimento feminista brasileiro está associada à luta das mulheres pelo reconhecimento de seus direitos políticos. Como destaca Freitas (1998), em “1930 surgem os primeiros grupos de mulheres que lutavam pelos seus direitos, principalmente o de voto, concedido em 1932 no governo de Getúlio Vargas” (FREITAS, 1998, p. 3). Direito este, conquistado pelas mulheres, mas que ficou mais conhecido como um ato de bondade pelo referido presidente.

Além da questão do voto, ocorreram também outras lutas de grupos de mulheres neste período. Pinto (2003) afirma que o feminismo é um movimento muito particular e mesclou nas suas lutas diversas ações e desafiou diferentes formas de organização da sociedade.

O feminismo tem provocado militâncias apaixonadas e raivas incontidas. Desde suas primeiras manifestações, ainda no século XIX o movimento foi muito particular, pois desafiou ao mesmo tempo a ordem conservadora que excluía as mulheres do mundo público - portanto, dos direitos como cidadã - e também as propostas revolucionárias, que viam na luta das mulheres um desvio da pugna do proletariado por sua libertação (PINTO, 2003, p.9).

Podemos depreender da citação de Pinto (2003), que as propostas dos grupos organizados de mulheres oscilam entre duas tendências: o revolucionarismo e o conservadorismo. A primeira tendência refere-se ao “feminismo bem comportado" de Bertha Lutz. E a segunda diz respeito, ao “feminismo mal comportado” realizado por diferentes grupos de mulheres que tinham um comportamento mais radical e que, influenciadas pelas idéias do anarquismo trazidas por imigrantes (italianos, espanhóis e 
portugueses) nas primeiras décadas do século XX, lutavam contra a dominação dos homens (PINTO, 2003).

E entre as mulheres anarquistas podemos citar Maria Lacerda de Moura, que é considerada uma das mais importantes feministas das décadas de 1920 e 1930 . Ao contrário das integrantes da Federação Brasileira para o Progresso Feminino, lideradas por Bertha Lutz, que possuíam uma “alta condição financeira” e eram representantes diretas da elite brasileira, Maria Moura era de família modesta e suas idéias feministas eram bastante amplas, pois “iam desde questões relacionadas com a participação política até a defesa aberta do amor livre e da educação sexual” (PINTO, 2003, p.36).

A mobilização das mulheres em relação às desigualdades de gênero presentes no mundo do trabalho que se intensificou no século $\mathrm{XX}$, ainda está presente na atualidade. Essa luta inclui reivindicações sobre o direito de trabalhar, para receberem de forma justa pelo trabalho que foi desempenhado e pelo pagamento de salários iguais aos recebidos pelos homens (ALVES; PITANGUY, 1985).

Nas décadas de 1960 e 1970 o feminismo (re)emerge de maneira significativa nos Estados Unidos e na Europa, em um período de magnitude e esplendor político e cultural destes locais. Tanto no território europeu quanto no norte americano havia um clima de “revolução dos costumes, de radical renovação cultural, enquanto que no Brasil o clima era de ditadura militar, repressão e morte (...), mas primordialmente ao longo desse período, surgiu e se desenvolveu o movimento feminista” (PINTO, 2003, p. 43).

No que tange a organização do feminismo brasileiro no período da ditadura, a autora Céli Pinto (2003) afirma que o feminismo nasce e também se desenvolve em um difícil paradoxo:

(...) ao mesmo tempo que teve de administrar as tensões entre uma perspectiva autonomista e sua profunda ligação com a luta contra a ditadura militar no Brasil, foi visto pelos integrantes desta mesma luta como um sério desvio pequeno-burguês (PINTO, 2003, p. 45).

Ainda sobre estas décadas, podemos conceber que, de 1964 a 1970 o movimento feminista brasileiro teve um caráter liberal, voltado para as reivindicações de seus direitos, em vários âmbitos da sociedade. Neste período houve uma nítida presença da Igreja Católica no movimento feminista e até mesmo na organização de certos grupos, uma vez 
que as igrejas eram um dos poucos locais para reunião e articulação do movimento no período ditadorial, devido às repressões e perseguições (FREITAS, 1998).

Durante todo o período em que o país esteve sob ditadura, grande parte das feministas estava envolvida ou era simpatizante das lutas contras esta forma opressora de organização política e social. Sendo que algumas destas feministas foram "presas, perseguidas e exiladas pelo regime” (PINTO, 2003, p. 45).

Para a autora Juliana Garcia de Freitas, em seu trabalho intitulado de: Gênero $e$ Violência “Uma reflexão sobre as mulheres na Casa Abrigo”, afirma que:

Assim, os primeiros grupos feministas que apareceram na década de 70 tiveram o compromisso de lutar tanto pela igualdade das mulheres como pela anistia e abertura democrática. Eram grupos de reflexão e pressão, e que tinham como tarefa traduzir sua motivação original em proposições que fossem relevantes para a grande massa de mulheres desprivilegiadas, de modo a mobilizá-las contra a opressão de sexo e de classe (FREITAS, 1998, p. 4).

Segundo Pinto (2003) no ano de 1975 o movimento feminista brasileiro passa por inúmeras situações que são verdadeiros marcos históricos do movimento no país. Primeiramente foi a decisão da Organização das Nações Unidas - ONU de considerar este ano como o “Ano Internacional da Mulher”, sendo este ano o primeiro da década da mulher. Outro fato marcante neste ano foi o início das reuniões anuais das feministas nos encontros da Sociedade Brasileira para o Progresso da Ciência - SBPC, tais reuniões duraram aproximadamente dez anos. Ainda sobre o ano de 1975, vale destacar o fato deste ser o ano em que se organizou o Movimento Feminino pela Anistia, sendo tal movimento extremamente necessário para a promulgação da anistia em 1979.

Ainda na década de 1970, os grupos feministas acirraram as suas lutas contra a violência contra as mulheres, principalmente depois do emblemático caso da morte de Leila Diniz, no ano de 1976. Estas lutas foram aprofundadas nas décadas de 1980 e 1990, que ficaram marcadas por campanhas contra o assassinato de mulheres e também pela implementação de políticas públicas.

Neste período a pressão dos vários grupos feministas resultou na instalação de um amplo debate e em importantes ações referentes à violência contra a mulher no Brasil. Durante anos, tais grupos articularam diversas ações que repercutiram em medidas 
governamentais, e “forçaram” o Estado brasileiro a assinar os acordos internacionais que visavam à erradicação da violência contra a mulher (CFEMEA, 2007).

A partir dos anos 80, podemos conceber que várias são as medidas adotadas pelo governo brasileiro relacionadas às reivindicações do movimento feminista. Dentre essas se destacam as medidas e ações relacionadas à violência como, por exemplo, a criação do Conselho Nacional dos Direitos da Mulher - CNDM e das Delegacias de Atendimento a Mulher - DEAMs em 1985 (CFEMEA, 2007).

Em 1979 o país passa por um período muito importante, que podemos dividir em dois momentos que não possuem ligação direta com o "feminismo" brasileiro, mas que “tiveram grande influência em seu desenvolvimento durante a década de 1980: a anistia aos presos e exilados políticos e a reforma partidária” (PINTO, 2003, p. 67). Devemos ressaltar que a anistia é um período em que há mais possibilidade de manifestação, e a reforma partidária pode ser compreendida como, uma maior liberdade em vários setores econômicos e políticos do país.

A reforma partidária no ano de 1979 foi extremamente importante para o movimento feminista, e foi a base para que se estruturasse as reivindicações do movimento na década de 80. Pois neste início de década podemos enumerar duas questões relevantes dos grupos feministas, a primeira diz respeito aos grupos temáticos que tratavam principalmente de violência contra a mulher e também sobre a sua saúde. A segunda questão refere-se ao nascimento e desenvolvimento do “feminismo acadêmico", sendo que algumas universidades criaram centros de pesquisas e estudos da mulher (PINTO, 2003).

Já em relação à reforma partidária devemos destacar a relevância desta no interior do movimento feminista e as respectivas modificações ocasionadas por tal reforma, uma vez que, a inexistência do bipartidarismo dividiu ainda mais o movimento, trazendo novos rumos para a articulação deste.

Ainda em relação à década de 1980 devemos também analisar no cenário mundial a articulação e acontecimento dos primeiros Encontros Latino-Americanos e do Caribe, sendo que este primeiro encontro aconteceu em Bogotá na Colômbia no ano de 1981, acontecendo ainda nesta década mais três encontros, e são eles: "Lima, Peru (1983), Bertioga, Brasil (1985), Taxco, México (1987)” (ALVAREZ, 2003, p. 544). 
Tais encontros tinham entre as suas participantes diversos grupos de mulheres (não necessariamente feministas), e grupos essencialmente feministas, com diferentes perspectivas e ideologias e inseridos em diferentes espaços públicos ou privados, dentro ou fora das instituições estatais. (ALVAREZ, 2003). Sobre a organização e acontecimento destes encontros na América Latina, América Central e no Caribe, destaca a autora:

Mais do que apenas um fértil espaço de confluência, esses Encontros regionais têm ajudado a 'imaginar' comunidades feministas latinoamericanas. Eles têm sido cruciais ao desafiar normas culturais nacionalistas masculinistas e ao criar uma gramática política feminista comum (mesmo que sempre contestada) (...) Os Encontros também promoveram novas modalidades de ativismo transfronteiras. De fato, um produto-chave desses diálogos tem sido a formação de numerosas redes infra-regionais que tratam de questões e identidades específicas, assim como coalizões de advocacy (ou de promoção e defesa de direitos) relacionadas a uma série de questões como a saúde da mulher e direitos sexuais e reprodutivos, violência contra a mulher, e representação política das mulheres (ALVAREZ, 2003, p. 543-544).

O movimento feminista brasileiro, também na década de 1980, teve papel ativo na construção da Constituição Federal de 1988. Em vários parágrafos da constituição há importantes direitos que dizem respeito à mulher e a sua condição como cidadã na sociedade.

Na década de 1990 o movimento feminista no Brasil passa por uma reestruturação. Assim na década de 90, o movimento foi 'dominado' e tornou-se um “feminismo profissionalizado das organizações não-governamentais (ONGs)”, como afirma Pinto (2003, p.82). Mas este episódio não ocorre apenas no Brasil, movimento semelhante pode ser percebido também na América Latina com um redimensionamento das estratégias do feminismo na região e o fato de haver uma maior influência “da advocacy de políticas”, como afirma Sônia E. Alvarez (2003, p.550).

Assim a incorporação de reivindicações do movimento feminista brasileiro na agenda pública e governamental, na década de 1990, se materializou entre outras iniciativas, na assinatura de três importantes acordos internacionais pelo Governo do Brasil. Outro passo importantíssimo foi dado em 2002, com a criação da Secretaria de Estado dos Direitos da Mulher - SEDIM, transformada em 2003 na Secretaria Especial de Políticas para as Mulheres - SPM. 
Vale ressaltar que estas e outras conquistas serão trabalhadas de forma mais aprofundadas no próximo item deste capítulo, e este possui como meta estabelecer a relação entre o movimento feminista, a elaboração de políticas públicas para as mulheres e a criação da Lei conhecida como "Maria da Penha”, que foi sancionada em agosto de 2006.

\subsection{Movimento Feminista e Políticas Públicas para as Mulheres}

A partir de suas lutas o movimento feminista propôs ações e debates sobre várias temáticas, como foi apresentado anteriormente. As suas lutas e reflexões principalmente no campo da violência trouxeram mudanças significativas em vários âmbitos (ANGELIM, 2004).

As feministas consideram que as formas de violência contra a mulher estão respaldadas nos pilares da desigualdade de gênero (PESSIS; MARTÍN, 2000). Mas não devemos esquecer que o conceito de gênero que propomos para este trabalho refere-se a uma construção social, histórica, cultural e psicológica tanto da feminilidade quanto da masculinidade, como é proposto por Scott (1995).

A autora Maria Ferreira Santos Farah, em seu artigo "Políticas públicas e gênero" debate a importância das ações governamentais relacionadas com a temática de gênero, mais precisamente com a desigualdade de gênero. Segundo a autora,

(...) as ações governamentais, as políticas públicas e os programas desenvolvidos por governos podem exercer um papel importante diante deste quadro de desigualdades: Podem reforçar as desigualdades, o que ocorre, em geral, pelo fato de os governos e as agências estatais não estarem "atentos" às desigualdades de gênero. E mais que isto, em decorrência também de a própria sociedade não está atenta a estas desigualdades. Mas as ações governamentais, as políticas públicas, podem também contribuir para a redução da desigualdade de gênero (FARAH, 2003, p.128).

No texto, Violência conjugal: os espelhos e as marcas, as autoras: Lia Zanotta Machado e Maria Tereza Bossi de Magalhães consideram que a 'nomeação' realizada pelo movimento feminista referente às desigualdades entre homens e mulheres foi um passo decisivo para a construção de políticas publicas sobre este temática da violência. Essas desigualdades descritas por Machado e Magalhães (1999) envolvem principalmente a 
questão da conjugalidade, pois acontecem em um espaço privado de relação entre homens e mulheres.

A nomeação de que as relações privadas entre homens e mulheres eram também relação de poder, de desigualdade e de violência permitiu a produção de políticas públicas sociais e pessoais que buscassem combater a violência privada e reformulassem as relações de poder na esfera privada. As políticas públicas sociais e pessoais que se seguiram levaram a um aprofundamento e à decifração dessas questões. Tiveram de se defrontar não só com as propostas de mudanças sociais e pessoais para os homens, criticando suas posições de poder e de violência, mas também se defrontaram com o reconhecimento da dificuldade de mudança para muitas mulheres de suas posições de vítimas (MACHADO; MAGALHÃES, 1999, p.174).

Na década de 1970 os grupos feministas acirraram as suas lutas contra a violência contra as mulheres, principalmente depois do emblemático caso da morte de Leila Diniz. Estas lutas foram aprofundadas nas décadas de 1980 e 1990. A década de 80 ficou marcada pela campanha contra o assassinato de mulheres, denominado de: “Quem Ama não Mata”, desencadeada com forte o apoio da mídia. Já 1990 recebeu ênfase pela formulação e implementação de políticas públicas específicas (CFEMEA, 2007). Sobre a década de 70 podemos enfatizar que:

Desde meados da década de 70, o movimento de mulheres tem lutado em defesa da igualdade de direitos entre homens e mulheres, dos ideais de direitos humanos, defendendo a eliminação de todas as formas de discriminação, tanto nas leis como nas práticas sociais. A ação organizada do movimento feminista foi decisiva para a especialização e supraestatalização dos direitos humanos das mulheres (CAVALCANTI, 2007, p. 19).

Estas lutas foram aprofundadas nas décadas de 1980 e 1990. A década de 80 ficou marcada pela campanha contra o assassinato de mulheres, denominado de: “Quem Ama não Mata”, desencadeada com forte o apoio da mídia. Já 1990 recebeu ênfase pela formulação e implementação de políticas públicas específicas (CFEMEA, 2007).

Outros fatos que foram desencadeados pela pressão dos grupos feministas, na década de 1980, é a criação do SOS Mulher nas cidades de São Paulo, Rio de Janeiro e Belo Horizonte em 1980, e o surgimento dos primeiros Conselhos Estaduais e Municipais de Direito da Mulher que ocorreu em 1983. 
Em 1984 o Brasil assina a Convenção sobre a Eliminação de Todas as Formas de Discriminação contra a Mulher - CEDAW. Tal convenção havia sido aprovada pela ONU, desde 1979. Após a assinatura desta convenção o Estado brasileiro começa a adotar medidas, e criar programas e instituições para a sensibilização e o combate da violência contra mulher. E no ano de 1985 o Brasil cria o Conselho Nacional de Direitos da Mulher CNDM.

Ainda no ano de 1985 surgem no Brasil às primeiras delegacias especializadas no atendimento às mulheres vítimas de violência conjugal. O objetivo da criação de tais delegacias era de oferecer as mulheres um espaço de escuta, pautado no respeito e na ética. Segundo Soares (1999):

As DEAMs, criadas na década de 80 , tinham como objetivo oferecer às mulheres vítimas de violência o tratamento digno e respeitoso que elas raramente recebiam nas delegacias distritais, onde os atendimentos tradicionais, oferecidos pelos policiais, se assemelhava, com freqüência, aos próprios atos que haviam motivado a queixa. Nas DEAMs, as mulheres encontrariam não apenas um tratamento melhor, mas também um atendimento especializado, por parte de uma instituição que reconheceria como crime as ações violentas que as teriam vitimado (SOARES, 1999, p. 49).

Na década de 90 quatros ações merecem destaque na questão da luta referente à violência contra mulher. Primeiro em 1993 o Brasil participa na Conferência Mundial de Direitos Humanos, realizada em Viena, vale ressaltar que neste momento a violência contra a mulher passou a ser reconhecida como uma violação dos direitos humanos.

Já a segunda ação aconteceu em 1994 quando o país assina a Convenção Intamericana para Prevenir, Punir e Erradicar a Violência contra a Mulher, tal convenção ficou conhecida como “Convenção de Belém do Pará”, e uma das suas medidas foi estabelecer que os países participantes desta criassem políticas públicas direcionadas para a questão da violência (CFEMEA, 2007).

Ainda na década de 90, mais especificamente no ano de 1995 acontece à terceira ação que foi anteriormente mencionada, tal ação é a Declaração e a Plataforma de Ação da IV Conferência Mundial sobre a Mulher, que aconteceu em Beijing. O Brasil também assinou esta declaração. 
Vale ressaltar que estas três ações mencionadas anteriormente compõem o Plano Nacional de Direitos Humanos - PNDH, elaborado na I Conferência Nacional de Direitos Humanos, em 1997, onde foram construídas as diretrizes para acabar com práticas que violam os direitos humanos (BRASIL, 2008).

A quarta ação acontece no ano de 1998, onde duas campanhas e um pacto marcaram ano em relação à luta contra as formas de violência contra a mulher. A primeira campanha foi promovida pelo Comitê Latino Americano e do Caribe para a Defesa dos Direitos da Mulher - CLADEM e recebeu o apoio do Centro Feminista de Estudos e Assessoria - CFEMEA, do Conselho Nacional de Direitos da Mulher e também se agências da ONU, tal campanha recebeu o nome de "Sem as Mulheres os Direitos não são Humanos".

E neste ano ainda foram lançadas o "Pacto Comunitário contra a Violência Intrafamiliar" e também a campanha "Uma vida sem Violência é um Direito Nosso", onde tanto o pacto quanto esta última campanha foram promovidos pelas Nações Unidas. Sendo que o pacto além de ter sido assinado pelo governo brasileiro, ainda foi assinado pelas organizações articuladas da sociedade civil (CFEMEA).

O século XXI é marcado por inúmeras transformações relacionadas à questão da violência contra a mulher. $\mathrm{O}$ fato de o Brasil ter assinado acordos e tratados internacionais sobre a temática anteriormente apresentada, e participado de encontros e conferências, propiciou um pano de fundo para que a luta dos movimentos feminista se ampliasse e atingisse proporções inéditas até aquele momento no país.

Em 2002 o país cria a Secretaria de Estado dos Direitos da Mulher - SEDIM, sendo que esta secretaria é transformada em 2003 na Secretaria Especial de Políticas para as Mulheres - SPM, e esta possui uma ligação direta com o Conselho Nacional dos Direitos da Mulher - CNDM.

O foco central de atuação dessas duas instâncias - SPM e CNDM - é articular e implementar programas e diversas ações que visem erradicar todas as formas de violência contra a mulher, e também promover a igualdade entre homens e mulheres.

Para o CFEMEA (2007), neste mesmo ano é lançado um documento que foi elaborado por mais de 5.000 ativistas, tal documento recebeu o nome de Plataforma Política 
Feminista, e sua aprovação se deu em junho de 2002 na Conferência Nacional de Mulheres Brasileiras. Outro fato que se desenvolveu neste ano se refere à formação de um consórcio entre juristas e as entidades feministas para estudar e elaborar um documento para um Projeto de Lei Integral.

O objetivo central deste Projeto Lei seria criar mecanismos na forma da lei que coibisse as inúmeras formas de violência doméstica e familiar contra a mulher, sendo que este também visava criar diretrizes para uma Política Nacional, para o enfrentamento de todas estas formas de violências.

Já no ano de 2003 além da transformação da SEDIM em Secretaria Especial de Políticas para as Mulheres - SPM, vale ressaltar que esta recebe status de ministério e representou um marco histórico no país, o Brasil entrega o seu primeiro relatório para o Comitê da Convenção sobre a Eliminação de Todas as Formas de Discriminação contra a Mulher (CEDAW). Este relatório correspondia desde a década de 1980, mas precisamente de 1985 até o ano de 2002. Após uma análise minuciosa de tal documento o Comitê da CEDAW recomenda ao Estado Brasileiro ações efetivas e rápidas, e também uma lei completa que combatesse a violência contra a mulher (BRASIL, 2007).

No ano de 2004 a SPM forma um Grupo Interministerial, tal grupo tinha como um dos seus objetivos começar as discussões sobre a questão da violência contra a mulher de forma mais sistematizada e pensar também medidas para serem adotadas para o cumprimento das recomendações do Comitê da CEDAW. O Grupo Interministerial utilizou o documento elaborado em 2002 pelo consórcio entre os juristas e as entidades feministas, como base (BRASIL, 2007).

E no segundo semestre de 2004 o Governo Federal representado pela SPM realiza a I Conferência Nacional de Políticas para as Mulheres. Esta Conferência contou com a participação direta nos debates de mais de 120 mil mulheres de todos os estados, e como decisões máximas das discussões e debates apresentaram propostas para a elaboração do Plano Nacional de Políticas para as Mulheres.

Segundo o CFEMEA (2007), antes da realização da I CNPM, ocorreram conferências municipais, estaduais e distritais. Nas CNPM participam, com direito ao voto, 
apenas mulheres credenciadas e identificadas como delegadas e que participaram das outras conferências em seus municípios e estados.

Fruto do debate ocorrido na I CNPM, o PNPM reconhece o dever do Estado frente ao enfrentamento das desigualdades entre homens e mulheres. Por meio de ações e políticas públicas, o Plano busca resgatar a dívida existente da nossa sociedade, historicamente sexista, com as mulheres. Além de ser resultado das pressões sociais internas à nossa sociedade, pode-se pensar o Plano também como resposta às pressões sofridas pelos órgãos externos ao país, em acordo com os diversos acordos assinados pelo Brasil em prol da defesa da mulher de sua promoção (BRASIL, 2007).

O Plano Nacional de Políticas para as Mulheres representa o amadurecimento dos anos de debate e também embate entre a sociedade civil (principalmente os Movimento feminista articulados) e o Estado. E este não consiste em uma política voltada apenas para o âmbito do trabalho ou da precarização do trabalho, pois este visa à execução de ações em uma perspectiva maior e altamente complexa.

Portanto este plano é uma política social que contrapõem o conceito defendido por Coimbra (1987) em: Será que o marxismo responde à pergunta de como surgem às políticas sociais?. Pois visto que o PNPM não tem como foco apenas, esta questão do trabalho ou da pobreza, mas objetiva analisar outros eixos, como, por exemplo, o eixo de enfretamento da violência contra a mulher. A seguir está definição do autor sobre tal políticas sociais:

As políticas sociais são precisamente as migalhas de que se falou. Elas representariam, portanto a moeda pela qual o Estado burguês compra a docilidade atual e o compromisso futuro da classe trabalhadora para com a manutenção do capitalismo, dando-lhe uma participação simbólica no consumo social que ao contrário de ser uma ameaça à realização do lucro, é uma das mais importantes guardiãs (COIMBRA, 1987, p.113).

Mas além do comentário acima não se enquadrar ao Plano Nacional de Políticas para as Mulheres - PNPM por focalizar de forma extremada a questão da pobreza e da miséria nas políticas públicas, podemos conceber que tal plano não representa uma moeda de compra do Estado em relação aos indivíduos e a sociedade.

Pois o PNPM foi elaborado conjuntamente com as organizações civis e com a sociedade de maneira geral, e possui de maneira singular a participação dos diversos 
movimentos feministas, uma vez, que tais movimentos conseguiram inserir na agenda pública as questões relacionadas ao gênero e a desigualdade de gênero. Depois de um longo período de democratização (CFEMEA, 2007).

As motivações existentes para tal elaboração são várias e ocorrem dentro de um contexto que pode ser resumido em uma correlação de forças entres três pólos: os movimento feminista, as exigências internacionais dadas por meio dos pactos entre os países e os trabalhos e pesquisas crescentes sobre desigualdade de gênero.

O PNPM é formado por 15 objetivos, que, de forma resumida, buscam abranger a mulher em todos seus aspectos e superar as desigualdades existentes. Esses objetivos consideram as diferenças regionais, as desigualdades enfrentadas pelas mulheres, a construção social a respeito das mulheres, entre outros aspectos.

O Plano se divide em quatro eixos principais: autonomia, igualdade no mundo do trabalho e cidadania; educação inclusiva e não sexista; saúde das mulheres, direitos sexuais e direitos reprodutivos; enfrentamento à violência contra as mulheres. Cada um desses eixos é permeado por objetivos, metas e prioridades, que buscam garantir a execução efetiva do Plano.

O primeiro eixo refere-se à autonomia, igualdade no mundo do trabalho e cidadania. Este eixo busca legitimar a mulher frente à sociedade. Pretende inseri-la nos debates políticos, decisões econômicas e no mercado de trabalho, considerando, sempre, suas especificidades.

No segundo eixo a atenção é para a educação inclusiva e não sexista. Busca reconhecer a mulher enquanto sujeito histórico e de relevância, além de promover uma educação livre de preconceito e discriminação, com inclusão massiva de mulheres no ambiente escolar.

O terceiro aborda a saúde das mulheres, direitos sexuais e reprodutivos. Neste eixo busca-se priorizar a atenção à saúde da mulher, garantindo programas especiais para seu atendimento. Busca-se, também, a garantia da mulher sobre seu próprio corpo e da extinção de qualquer tipo de violência contra ele.

No quarto eixo, Enfrentamento à violência contra as mulheres, o PNPM tem como objetivos implantar uma política de enfrentamento a violência contra a mulher e que esta 
garanta um atendimento integrado a estas mulheres. Tal plano também objetiva reduzir os índices de violência contra a mulher e garantir que haja o cumprimento dos acordos internacionais que foram explicados anteriormente, e realizar uma revisão da legislação brasileira sobre a violência contra as mulheres.

Desta maneira podemos considerar que, a criação da Lei 11.340/2006, mais conhecida como “Lei Maria da Penha”, recebeu uma forte influência dos movimentos sociais e dos feministas, de maneira especifica. Esta lei foi promulgada depois de vários anos de luta do Movimento feminista, e também da sociedade civil de maneira geral.

No objetivo do quarto item do PNPM, e em outras partes do plano, há a explicação da importância de criar mecanismos para erradicar a violência contra a mulher. Assim como a justificativa para a criação de instituições para encaminhamento e acompanhamento, tantos para as mulheres quanto para os homens. Tal questão fica mais evidente nos passos que são definidos para alcançar os objetivos e também na parte do plano que sinaliza a criação de redes de atendimento as mulheres vítimas de violência. Essa e outras questões referentes ao tema foram contempladas coma promulgação da Lei 11.340/2006, conhecida como “Lei Maria da Penha” (CFEMEA, 2007).

O próximo capítulo intitulado de: A Lei “Maria da Penha” e a importância da articulação de redes, apresentará as modificações da lei em inúmeros aspectos, mas o foco serão os artigos que se referem a articulação dos serviços e programas. No último item do referido capítulo será apresentada a importância de articulação de redes e os conceitos relacionados à rede, que significa um dos conceitos-chave desta monografia. 


\section{Capítulo 4 - A Lei "Maria da Penha" e a importância da articulação de rede}

A lei 11.340 foi sancionada em agosto de 2006, e tem por principal objetivo coibir todas as formas de violência contra a mulher. Antes da criação desta lei os crimes perpetrados contra a mulher eram apurados e julgados com base na Lei 9.099 de 1995, que julga os crimes de menos poder ofensivo.

Segundo o Centro Feminista de Estudos e Assessoria - CFEMEA ocorreram muitos debates e reflexões para a criação da "Lei Maria da Penha", e um dos debates fundamentais foi o de considerar a violência perpetrada contra a mulher como uma violação dos direitos humanos. A seguir está expressa uma citação do CFEMEA sobre alguns dos anseios da já referida lei:

(...) a Lei busca promover uma real mudança nos valores sociais, que naturalizam a violência que ocorre nas relações domésticas e familiares, em que os padrões de supremacia masculina e subordinação feminina, durante séculos, foram aceitos por toda a sociedade. Neste cenário é que a Lei apresenta, de maneira detalhada, os conceitos e as diferentes formas de violência contra a mulher, pretendendo ser um instrumento de mudança política, jurídica e cultural (CFEMEA, 2007, p. 11).

As diferenças existentes entre: a Lei $n^{\circ}$. 9.099/1995 e a Lei $n^{0}$. 11.340/2006 são enormes, e isto pode ser percebido de forma bastante nítida na citação acima, uma que esta última lei busca promover uma mudança nos valores sociais relacionados à questão da violência contra a mulher.

A promulgação, em 2006, da lei que objetiva principalmente coibir todas as formas de violência contra a mulher, representou um importante passo do governo brasileiro, mas devemos ressaltar que esta não foi elaborada do dia para a noite, e não contou apenas com os “desejos governamentais” para que sua implementação fosse efetivada.

No capítulo anterior apresentamos uma breve trajetória do movimento feminista no Brasil e no mundo, assim como as relações existentes entre as suas lutas e a criação de políticas públicas específicas para as mulheres, e também com o enfrentamento das desigualdades de gênero, principalmente nas questões relacionadas à violência. Também debatemos o contexto político e social para a criação da Lei nº. 11.340 de 2006. 
A Lei $n^{\circ}$. 11.340, sancionada em agosto de 2006, ficou conhecida pelo nome de “Lei Maria da Penha”, em homenagem à mulher, de mesmo nome, que lutou durante 20 anos para que seu ex-marido (ex-professor universitário) fosse realmente punido, após tentar assassiná-la por duas vezes, uma vez com arma de fogo e outra vez tentou eletrocutála e afogá-la. As conseqüências irreversíveis à sua saúde, como por exemplo, a paraplegia, além de outras seqüelas causadas pela violência e as tentativas de homicídio, não impediram Maria da Penha de transformar toda a sua dor em luta. E com o apoio dos grupos feministas conseguiu que seu caso fosse levado até as últimas instâncias nacionais e internacionais de direitos humanos da ONU, e assim decretar a prisão de seu agressor. (BRASIL, 2006).

Desta maneira podemos enfatizar que a criação de políticas públicas destinadas a erradicar as formas de violência contra a mulher e a própria promulgação da Lei "Maria da Penha”, possuem em seu cerne uma relação direta com o movimento feminista. Mas devemos explicar que não há, porém, entre os diferentes grupos, uma unidade e um ‘consenso’ sobre as ações a serem executadas, nas políticas e na própria lei.

O “caso Maria da Penha” é exemplo da força dos movimentos feministas em proporcionar a visibilidade necessária para as questões da violência contra a mulher. Para Fábio Angelim (2004), a força e articulação do movimento feminista possibilitaram uma crítica ao modelo de intervenção executado pelo Estado, além de questionar a suposta ‘naturalização’ da violência dos homens contra as mulheres.

As violências domésticas e familiares contra a mulher, incluindo a violência conjugal, começou a ser punida inicialmente, no Brasil, por intermédio da Lei nº 9.099, de 26 setembro de 1995, que dispõe sobre os Juizados Especiais Cíveis e Criminais e dá outras providências. Cavalcanti (2007) enfatiza que a promulgação desta lei foi considerada como um grande avanço na legislação brasileira. Assim, segundo Cavalcanti (2007, p.165):

A Lei ${ }^{\circ}$. 9.099/95 tem sido saudada como um dos maiores avanços da legislação brasileira por sua proposta despenalizante, ao introduzir importantes mudanças na política criminal brasileira, como a aplicação de penas não privativas de liberdade a determinados delitos, definidos como de menor poder ofensivo. Surgida, por um lado, no contexto internacional de informalização do Poder Judiciário e, por outro, na constatação da complexidade da sociedade moderna em que a repressão é incapaz de resolver determinados conflitos sociais, bem como em razão de que essa 
criminalidade "menor" atrapalhava o andamento dos chamados crimes maiores e de alta lesividade. Assim, com a instituição dos juizados, os magistrados puderam dedicar mais tempo aos crimes mais graves.

Quando julgada e punida nos parâmetros da Lei 9.099, a violência praticada contra a mulher era considerada assim, como um crime de menor poder ofensivo. Neste caso o agressor receberia pena máxima de 2 (dois) anos, e as penas constantemente aplicadas nestas situações eram: o pagamento de cestas básicas, pagamento de multas e/ou a prestação de serviços à comunidade.

Para Cavalcanti (2007) a maioria dos delitos cometidos contra as mulheres e que são apurados pelos Juizados Especiais Criminais se referem às lesões corporais consideradas leves, desta forma seriam lesões que não gerariam um perigo de vida de forma direta, e que possibilitaria a recuperação da pessoa vítima de violência, não causando a esta “incapacidade para as ocupações habituais por mais de 30 dias” (CAVALCANTI, 2007, p.168).

Em relação à questão das lesões corporais, Cavalcanti (2007, p. 168) assinala que:

(...) a mulher poderia ser espancada, torturada e ficar à beira da morte, mas, se recuperasse a saúde no prazo de 30 dias e não apresentasse seqüelas, o delito era considerado de menor potencial ofensivo com pena que variava de 6 (meses) a 1 (um) ano de reclusão, sujeito ao rito dos juizados especiais, pena restritiva de direito ou multa, facilmente convertido em prestação de serviços à comunidade ou pagamento de cestas básicas. O que era incoerente e um verdadeiro absurdo. Ademais, as seqüelas psicológicas que essas agressões acarretavam às vítimas não eram observadas na aplicação da pena, bem como o fato de as agressões serem, geralmente, habituais.

A criação da Lei “Maria da Penha” estipulou novos mecanismos para coibir as inúmeras formas de violência doméstica e familiar contra a mulher, retirando estas violências (psicológica, física, sexual, patrimonial e moral) da categoria dos crimes considerados de menor poder ofensivo. Esta nova lei permite que os agressores sejam presos em flagrantes ou que tenham ainda a prisão preventiva decretada, além de não haver a estipulação das penas de prestação de serviços à comunidade, pagamento de cesta básica e/ou multa, sendo tais questões, inovações importantes da Lei no . 11.340/2006 como se verá a seguir, no primeiro item desse capítulo. 


\subsection{As inovações da Lei $n^{0} .11 .340 / 2006$}

A Lei 11.340/2006, a "Maria da Penha", inova em seus mecanismos que visam coibir as formas de violência doméstica e familiar contra a mulher. E inova também na forma como deve ser conduzida a ação realizada por juízes, promotores, policiais e demais profissionais no julgamento e/ou acompanhamento dos casos de violência.

Esta lei compreende que as questões da violência contra a mulher que chegam à justiça são complexas, e que necessitam, portanto, de ações mais articuladas. A citação a seguir realiza um resumo sobre os objetivos estipulados por esta lei.

Desde o começo dos debates para a criação da Lei 11.340/2006, a idéia principal foi caracterizar a violência domestica e familiar como violação dos direitos humanos das mulheres e elaborar uma Lei que garantisse proteção e procedimentos policiais e judiciais humanizados para as vítimas. Sob essa ótica, muito mais que punir, a Lei Maria da Penha traz aspectos conceituais e educativos, que a qualificam como uma legislação avançada e inovadora, seguindo a linha de um Direito moderno, capaz de abranger a complexidade das questões sociais e o grave problema da violência doméstica e familiar (CFEMEA, 2007, p.11).

Sobre este mesmo assunto, Cavalcanti (2007) considera que a Lei "Maria da Penha” possui como característica essencial à assistência destinada às vítimas, e também aos agressores, além de mecanismos que visam prevenir novas ocorrências da violência na justiça. A autora afirma que a Lei nº 11.340/06 é:

(...) uma lei que tem mais o cunho educacional e de promoção de políticas publicas de assistência às vítimas que a atenção de punir mais severamente os agressores dos delitos domésticos, pois prevê em vários dispositivos medidas de proteção à mulher em situação de violência doméstica e familiar, possibilitando uma assistência mais eficiente e a salvaguarda dos direitos humanos das vítimas (CAVALCANTI, 2007, p. 175 e 176).

Assim objetivando atender a esta complexidade de questões a lei foi dividida em 7 (sete) títulos: listar. Esses títulos abarcam 46 (quarenta e seis) artigos, que abordam temas como, por exemplo: gênero, raça, violência, assistência e políticas voltadas à mulher e ao agressor, equipes multidisciplinar, entre outros.

Discutiremos neste item os principais artigos de cada título, relacionando-os com as determinações inscritas na Lei 9.099/95, haja vista que esta lei orientou o judiciário em relação à violência doméstica e familiar contra a mulher, antes da criação da Lei $\mathrm{n}^{\circ}$. 11.340/2006. 
O Título I é dedicado às Disposições Preliminares e compreende os 4 (quatro) primeiros artigos da lei. E o mesmo inicia-se afirmando que a lei 11.340 cria mecanismos para coibir e também prevenir as formas de violência contra a mulher, e justifica que tais mecanismos são baseados nos termos apresentados na Constituição Federal promulgada em 1988, na Convenção Intamericana para Prevenir, Punir e Erradicar a Violência contra a Mulher, conhecida popularmente como Convenção de Belém do Pará, que foi assinada pelo governo brasileiro em 1994, sendo ratificada em 1995.

E também nos termos da Convenção sobre a Eliminação de Todas as Formas de Discriminação contra a Mulher - CEDAW, da ONU que havia sido assinada pelo Brasil em 1984, e de outros acordos ou tratados internacionais que foram assinados pelo país e que trazem questões referentes à temática da violência contra a mulher.

$\mathrm{O} 2^{\circ}$ (segundo) artigo deste título traz uma importante inovação, pois este enfatiza que independentemente da cultura, faixa etária, da questão econômica e social, e da orientação sexual da mulher vítima de violência, serão asseguradas as oportunidades para tais viverem sem violência. A seguir está exemplificado tal artigo:

Art. $2^{\circ}$ Toda mulher, independentemente de classe, raça, etnia, orientação sexual, renda, cultura, nível cultural, idade e religião, goza dos direito fundamentais inerentes à pessoa humana, sendo lhe asseguradas as oportunidade e facilidade para viver sem violência, preservar sua saúde física e mental e seu aperfeiçoamento moral, intelectual e social (BRASIL, 2006, p.15).

Vale destacar ainda que, neste artigo é apresentado uma importante inovação relacionada com a orientação sexual. Esta questão enfatiza que a violência independe da orientação sexual da mulher, uma vez que esta pode ocorrer entre duas mulheres que convivem de forma afetiva.

O Título II - Da violência doméstica e familiar contra a mulher, abarca dois capítulos: o primeiro ilustra as disposições gerais da referida lei e contém dois artigos: $5^{\circ}$ (quinto) e $6^{\circ}$ (sexto). Já o segundo capítulo discute as formas de violência contra mulher e compreende o $7^{\circ}$ (sétimo) artigo.

No primeiro capítulo podemos estabelecer como inovação a conceitualização realizada sobre a violência doméstica e familiar, tal fato está expresso no $5^{\circ}$ (quinto) artigo. Desta forma a lei estipula que a violência contra a mulher pode acontecer por ação ou 
omissão, no âmbito da unidade doméstica, no âmbito da família e em qualquer relação de afeto em que o agressor conviva, ou já conviveu com a vítima em algum momento.

Ainda sobre o artigo $5^{\circ}$ (quinto), podemos destacar que o termo família é utilizado de maneira ampla. Segundo o CFEMEA (2007, p.15) tal artigo “(...) entende-se por família a união de pessoas relacionadas de forma espontânea e afetivamente, sejam ou não aparentadas, vivam ou não sobre o mesmo teto, hetero ou homossexuais".

Já o $7^{\circ}$ (sétimo) artigo traz um dos mais significativos avanços desta lei, pois o mesmo tipifica quais são as formas de violência contra a mulher, e as denomina com sendo: física, psicológica, sexual, patrimonial e moral. Na Lei 9.099/95, não há nenhuma especificação destas formas de violência. Assim devemos compreender que estabelecer estas formas de violência não é uma mera formalidade, mas um dos mecanismos utilizados para que se possa compreender as complexas situações que envolvem a violência contra a mulher.

A assistência à mulher em situação de violência doméstica e familiar é objeto do Título III, que é subdividido em três capítulos. O primeiro capítulo refere-se às medidas integradas de prevenção, e faz parte deste capítulo o $8^{\circ}$ (oitavo) artigo, sendo que o mesmo é composto de nove incisos. Merece atenção o fato desse artigo mencionar que visando coibir a violência doméstica e familiar contra a mulher, às políticas públicas devem acontecer por intermédio de um "conjunto articulado de ações da União, do Distrito Federal e dos Municípios e das ações governamentais” (BRASIL, 2006, p. 18).

$\mathrm{O}$ segundo capítulo deste título diz respeito à assistência direcionada a mulher vítima de violência doméstica e familiar e tal questão está inserida no $9^{\circ}$ (nono) artigo. Este artigo reafirma que a assistência destinada à mulher vítima de violência deve ocorrer de maneira articulada. No parágrafo primeiro ainda deste artigo, existe a ênfase de que, o próprio juiz determinará o cadastramento de tais mulheres em programas de assistência nos níveis: federal, estadual e municipal.

O último e terceiro capítulo desta seção, denominado "Do atendimento pela autoridade policial” possui três artigos $\left(10^{\circ}, 11\right.$ e 12). Destacaremos o artigo 11 (onze), pois este enumera como deve ser o serviço prestado pela autoridade policial para a mulher: 
Art. 11. No atendimento à mulher em situação de violência doméstica e familiar, a autoridade policial deverá, entre outras providências:

I - garantir proteção policial, quando necessário, comunicando de imediato ao Ministério Público e ao Poder Judiciário;

II - encaminhar a ofendida ao hospital ou posto de saúde e ao Instituto Médico Legal;

III - fornecer transporte para a ofendida e seus dependentes para abrigo e local seguro, quando houve risco de vida;

IV - se necessário, acompanhar a ofendida para assegurar a retirada de seus pertences do local da ocorrência ou do domicílio familiar;

$\mathrm{V}$ - informar à ofendida os direitos a ela conferidos nesta lei e os serviços disponíveis (BRASIL, 2006, p. 21).

O Título IV é dedicado aos procedimentos e apresenta, na primeira parte, as disposições gerais e compreende o primeiro capítulo, que abarca do artigo 13 (treze) ao 17 (dezessete). Destes artigos três merecem nossa atenção especial, são eles o 14 (quatorze), o 16 (dezesseis) e o 17 (dezessete). No artigo 14 existe a especificação de que poderão ser criados os Juizados de Violência Doméstica e Familiar contra a Mulher, tais juizados deverão ter tanto competência civil quanto criminal.

Ainda sobre o primeiro capítulo deste título vale ressaltar que no artigo 16 está expresso que a renúncia á representação (renúncia ao processo) acontecerá em um audiência perante o juiz, mas antes deverá ser ouvido o ministério público. Esta audiência é denominada de "audiência de retratação” e torna-se extremamente necessária, pois muitas vezes as mulheres agredidas são coagidas a retirarem a queixa e desistirem do processo, este fato era muito recorrente quando os crimes de violência contra a mulher eram julgados pela Lei nº. 9.099/1995 (CAVALCANTI, 2007).

O último artigo deste primeiro capítulo que vale ressaltar é o 17, pois este explica que é vedado alguns tipos de penas aos agressores no caso da violência perpetrada contra a mulher, merece destaque o fato destas penas terem sido usado com freqüência pela lei $\mathrm{n}^{\circ}$ 9.099/95. A seguir está especificado na íntegra o que prevê tal artigo da lei nº.11.340/2006:

Art. 17. É vedada a aplicação, nos casos de violência doméstica e familiar contra a mulher, de penas de cesta básica ou outras de prestação pecuniária, bem como a substituição de pena que implique o pagamento isolado de multa (BRASIL, 2006, p.23).

Já o segundo capítulo deste título refere-se às medidas protetivas de urgência, e é composto de três seções. Vale destacar neste caso cada uma das seções, a primeira diz respeito às disposições gerais do capítulo, a segunda seção sobre as medidas protetivas de 
urgência que obrigam o agressor e a segunda são as medidas protetivas de urgência à ofendida.

Nas disposições gerais sobre as medidas protetivas de urgência, o artigo 20 expressa que independentemente da fase em que se encontra o inquérito policial poderá ser decretada a prisão preventiva do agressor. E como complemento do artigo anteriormente mencionado pode-se destacar o que especifica o artigo 21, que a “(...) ofendida deverá ser notificada dos atos processuais relativos ao agressor, especialmente dos pertinentes ao ingresso e à saída da prisão” (BRASIL, 2006, p. 24).

Ainda no tange ao artigo 21 deve-se discutir o que é abordado em seu parágrafo único: “A ofendida não poderá entregar intimação ou notificação ao agressor” (BRASIL, 2006, p.24), sendo este parágrafo um grande avanço da Lei $n^{\circ}$. 11.340/06. Pois na Lei $n^{\circ}$. 9.099/95 a mulher vítima de violência fazia a ocorrência na delegacia e levava para casa a intimação ou notificação para ser entregue para o marido, tal fato em inúmeras vezes gerava novos episódios de violência.

Segundo pesquisa "Percepção e reações da sociedade sobre a violência contra a mulher” realizada pelo Ibope e o Instituto Patrícia Galvão no ano de 2006 e antes da promulgação da Lei Maria da Penha, existe a afirmação de que: “33\% dos entrevistados (homens e mulheres) afirmaram que quando o marido fica sabendo da denúncia, reage, e a mulher apanha mais” (CFEMEA, 2007, p. 34).

A terceira seção do capítulo 2 (dois) refere-se às medidas protetivas de urgência à ofendida. Nesta seção destacamos o artigo 23 (vinte e três), pois este fala das medidas tanto para a mulher quanto para os filhos que esta por ventura tiver:

Art. 23. Poderá o juiz, quando necessário, sem prejuízo de outras medidas: I - encaminhar a ofendida e seus dependentes a programa oficial ou comunitário de proteção ou de atendimento;

II - determinar a recondução da ofendida e a de seus dependentes ao respectivo domicílio, após afastamento do agressor;

III - determinar o afastamento da ofendida do lar, sem prejuízo dos direitos relativos a bens, guarda dos filhos e alimentos;

IV - determinar a separação de corpos (BRASIL, 2006, p.26).

Já o terceiro capítulo deste título faz referência à atuação do Ministério Público, e neste está presente os artigos 25 (vinte e cinco) e o 26 (vinte e seis). Aqui merece atenção especial o artigo 26, pois este especifica quais são as atribuições que caberá ao Ministério 
Público. Destas atribuições destacaremos o segundo inciso do artigo, pois este é extremamente relevante:

Art. 26. (...) II - fiscalizar os estabelecimentos públicos e particulares de atendimento a mulher em situação de violência doméstica e familiar, e adotar, de imediato, as medidas administrativas ou judiciais cabíveis no tocante a quaisquer irregularidades constatadas (BRASIL, 2006, p. 27).

Ainda neste título está presente o capítulo 4 (quatro) que é sobre a assistência judiciária e neste devemos destacar o artigo 28 (vinte oito), pois este especifica que:

Art. 28. É garantido a toda mulher em situação de violência doméstica e familiar o acesso aos serviços de Defensoria Pública ou a assistência Judiciária Gratuita, nos termos da lei, em sede policial e judicial, mediante atendimento específico e humanizado (BRASIL, 2006, p. 27).

Observamos ainda que, o artigo 27 (vinte e sete) é um complemento do artigo anteriormente citado, pois este afirma que: "Em todos os atos processuais, cíveis e criminais, a mulher em situação de violência doméstica e familiar deverá estar acompanhada de advogado” (BRASIL, 2006, p. 27).

O Título $V$ merece atenção especial, uma vez que trata da equipe de atendimento multidisciplinar, uma das principais inovações da Lei $\mathrm{n}^{0}$. 11.340/2006. Dos quatro artigos (29 a 32) que compõem esta seção, destacamos o artigo 30 (trinta) e o 32 (trinta e dois).

No artigo 30 estão apresentadas as competências da equipe multidisciplinar, e este está especificado a seguir:

Art.30. Compete à equipe de atendimento multidisciplinar, entre outras atribuições que lhe forem reservadas pela legislação local, fornecer subsídios por escrito ao juiz, ao Ministério Público e à Defensoria Pública, mediante laudos ou verbalmente em audiência, e desenvolver trabalhos de orientação, encaminhamento, prevenção e outras medidas, voltados para a ofendida, o agressor e os familiares, com especial atenção às crianças e aos adolescentes (BRASIL, 2006, p.27 e 28).

Já no artigo 32 (trinta e dois) existe a especificação de que o Poder Judiciário no que tange a sua proposta orçamentária e com base na lei de Diretrizes Orçamentárias, “poderá prever recursos para a criação e manutenção da equipe de atendimento multidisciplinar” (BRASIL, 2006, p.28). Tal questão também será abordada no último título da lei.

Os Títulos VI e VII são dedicadas às Disposições Transitórias e às Disposições Finais, respectivamente. O primeiro dos dois é composto apenas pelo artigo 33 (trinta e 
três) e este estipula que as varas criminais acumularão tanto as competências cíveis quanto as criminais sobre os casos de violência doméstica e familiar contra a mulher. Isto enquanto não forem criados e estruturados os Juizados de Violência Doméstica e Familiar contra a Mulher.

Do Título VII, formado por treze artigos (34 a 46), destacamos três, que trazem inovações importantíssimas sobre a questão da violência contra a mulher. São eles: os artigos 37, 38 e 41.

O artigo 37 (trinta e sete) diz respeito à defesa dos interesses e também dos direitos transindividuais, e afirma que estes poderão ser exercidos tanto pelo Ministério Público MP quanto por associações que atuem na área. O texto do CFEMEA (2007, p. 35) explica que os direitos transindividuais,

(...) são direitos que não se destinam a uma pessoa especifica, e sim a um grupo ou segmento da sociedade. Ou seja, atingem um grande número de pessoas que podem ser conhecidos ou não. São divididos em direitos difusos, coletivos e individuais homogêneos.

Assim podemos perceber que os direitos transindividuais referentes a Lei "Maria da Penha” dizem respeito a todas as mulheres e não somente a mulher isolada vítima de violência doméstica e familiar, apesar de tais direitos também garantir as especificações de cada pessoa.

Já no artigo 38 (trinta e oito) existe a referência sobre as estatísticas da temática relacionada com violência contra a mulher. A seguir está expressa a citação do artigo:

Art. 38. As estatísticas sobre a violência doméstica e familiar contra a mulher serão incluídas nas bases de dados dos órgãos oficiais do Sistema de Justiça e Segurança a fim de subsidiar o sistema nacional de dados e informações relativo às mulheres (BRASIL, 2006, p. 29).

Por fim, o artigo 41 deste título, ressalta que aos “crimes praticados com violência doméstica e familiar contra a mulher, independentemente da pena prevista, não se aplica a Lei n 9.099” (BRASIL, 2007, p.30).

No próximo item deste capítulo iremos discutir sobre a articulação de redes. Mas para realizar tal discussão utilizaremos como base artigos já mencionados neste capítulo assim como os conceitos de alguns teóricos sobre o referido tema. 


\subsection{A importância da articulação de redes}

Neste item abordaremos especificamente os artigos da Lei $\mathrm{n}^{0}$. 11.340/2006, que tratam da criação e articulação de políticas, serviços e programas voltados para a temática da violência doméstica e familiar contra a mulher.

O artigo 35 (trinta e cinco) coloca em destaque a necessidade da União, Distrito Federal, Estados e municípios enfrentarem a problemática sobre a violência doméstica e familiar contra a mulher, de forma articulada, com o envolvimento de diferentes instâncias governamentais e profissionais.

Art.35. A União, o Distrito Federal, os Estados e os Municípios poderão criar e promover no limite das respectivas competências:

I - centros de atendimento integral e multidisciplinar para mulheres e respectivos dependentes em situação de violência doméstica e familiar; II - casas-abrigos para mulheres e respectivos dependentes menores em situação de violência doméstica e familiar;

III - delegacias, núcleos de defensoria pública, serviços de saúde e centros de perícia médico-legal especializados no atendimento à mulher em situação de violência doméstica e familiar;

IV - programas e campanhas de enfrentamento da violência doméstica e familiar;

$\mathrm{V}$ - centros de educação e de reabilitação para os agressores (BRASIL, 2006, p. 28).

Além do artigo 35 (trinta e cinco), os artigos $3^{\circ}$ (terceiro), $8^{\circ}$ (oitavo) e $9^{\circ}$ (nono) também tratam de questões relacionadas à criação e/ou articulação de políticas, serviços e programas, estipulando competência e responsabilidade dos órgãos e autoridades pela criação e promoção dos mesmos (CFEMEA, 2007).

$\mathrm{O}$ artigo $3^{\circ}$ (terceiro) apresenta em seu texto uma especificação relacionada ao desenvolvimento de políticas relacionadas à esfera doméstica e familiar por parte do poder público. E estas políticas devem possuir como foco a garantia dos direitos humanos para as mulheres.

No artigo $8^{\circ}$ (oitavo) existe a afirmação de que a política pública destinada a coibir a violência na esfera doméstica e familiar será feita por intermédio “(...) de um conjunto articulado de ações da União, dos Estados, do Distrito Federal e dos Municípios e das ações não - governamentais” (BRASIL, 2006, p. 18). Mas vale ressaltar que este artigo estipula a criação e articulação de políticas, serviços e programas em inúmeras áreas: segurança, saúde, educação e assistência. 
Já o artigo $9^{\circ}$ (nono) refere-se de maneira clara ao campo da assistência que deve ser destinada à mulher vítima de violência:

Art. $9^{\circ}$. A assistência à mulher em situação de violência doméstica e familiar será prestada de forma articulada e conforme os princípios e as diretrizes previstos na Lei Orgânica de Assistência Social, no Sistema Único de Saúde, no Sistema Único de Segurança Pública, entre outras normas e políticas públicas de proteção, e emergencialmente quando for o caso (BRASIL, 2007, p. 19).

A análise desses artigos revela que a noção de rede constitui um aspecto central da proposta de atendimento às mulheres vítimas de violência. Nesse contexto considera-se importante abordar alguns dos significados atribuídos ao termo no debate contemporâneo, de modo a contextualizar o processo e as estratégias utilizadas para viabilizar a articulação entre políticas, serviços e programas, no âmbito da Lei Maria da Penha.

Para o autor Eugênio Vilaça Mendes, que desenvolve sua reflexão sobre rede tendo como referência, a atenção à saúde:

A idéia de redes de atenção à saúde convoca uma outra interpretação, conceitual e operacional, da atenção primária à saúde como estratégia de organização dos sistemas de saúde, ou seja, com a capacidade de apropriar e reordenar todos os recursos do sistema para satisfazer às necessidades da população. (MENDES, 2007, p. 21).

Para Faleiros e Faleiros (2001), a rede consiste na interação e aliança de forças entre os diferentes atores/ sujeitos, e entre estes e as forças existentes na sociedade ou até mesmo forças com valores simbólicos, e vale ressaltar que a rede está inserida em contextos sociais e políticos. As ações das redes podem ocorrer tanto no nível político quanto no nível operacional. Assim a articulação de rede possui importância fundamental para o enfrentamento da problemática da violência contra a mulher.

Carreira e Pandjiarjian (2003), destacam que a rede de serviços deve ser analisada por intermédio de ações conjuntas, e também com o aprimoramento de métodos de intervenção, pois esta pode ser uma estratégia amplamente relevante e desafiadora no combate da violência contra a mulher.

Faleiros (1999) destaca a existência de redes abertas e fechadas.

As estratégias de fortalecimento do usuário, na particularidade do trabalho social, precisam articular as mediações presentes nas redes abertas, fundadas no relacionamento intersubjetivo, com as existentes nas redes mais ou menos fechadas, pelos contornos biológicos, ecológicos, 
religiosos ou outros. Estas se aproximam mais do que se define como redes primárias, que se configuram mais significativas para o eu, como as relações afetivas familiares e de amizade. As redes secundárias são formais, institucionalizadas e dizem respeito à socialização do sujeito e os vínculos sociais mais amplos. (FALEIROS, 1999, p. 57 e 58).

Para este autor, a articulação da rede de atendimento com diversos programas, projetos, organizações governamentais e não governamentais e serviços, é imprescindível para o fortalecimento do cidadão. Esta articulação é importante até mesmo para uma maior clareza nos atendimentos e nas informações que são repassadas para os usuários destes serviços (FALEIROS, 1999).

Na problemática da violência contra a mulher esta articulação de rede, de acordo com Ghesti, Roque e Moura (2006), torna-se realmente necessária, para que seja alcançada uma operacionalização ampla das conquistas que foram adquiridas com a Lei Maria da Penha.

Um aspecto importante para a criação, o funcionamento e a articulação dos serviços, políticas e programas de modo a constituírem uma é a disponibilidade de recursos financeiros.

Para que todos os serviços sejam criados, formando uma rede integrada entre as várias redes e poderes (art. $8^{\circ}$, inciso I), são necessários recursos financeiros devidamente previstos no planejamento governamental. Por isso, a Lei determina que União, Distrito Federal, estados e municípios devem promover a adaptação de seus órgãos e programas, e incluir recursos específicos em seus orçamentos anuais (artigos 36 e 39) (CFEMEA, 2007, p.20).

As definições que foram apresentadas neste capítulo, principalmente sobre o conceito de rede, assim como os conceitos teóricos apresentados nos capítulos anteriores serão fundamentais para o capítulo de fechamento deste trabalho. Pois no próximo capítulo serão apresentados os dados sobre a pesquisa realizada para esta monografia, e estes serão correlacionados com os conceitos abordados neste trabalho. 


\section{Capítulo 5 - Os serviços de atendimento às mulheres vítimas de violência conjugal do DF na perspectiva da equipe do SERAV}

\subsection{Metodologia da pesquisa}

Delimitou-se que este estudo focalizaria somente os processos referentes à violência doméstica e familiar contra a mulher, atendidos pela $1^{\mathrm{a}}$ Vara do Juizado de Violência Doméstica e Familiar de Brasília - JUFAM e encaminhados ao NUPS/SERAV, que se encontravam já finalizados e devolvidos à juíza responsável, por ocasião do trabalho de campo, sendo que este foi realizado entre 29 de novembro e 03 de dezembro de 2007. Foram considerados todos os processos que envolviam alguma forma de violência contra a mulher. A análise indicou a existência de 61 processos acompanhados pelo NUPS/SERAV no período de datados de novembro de 2006 a janeiro de 2007.

Esse total não representa nem $10 \%$ dos mais de mil processos relacionados à violência contra a mulher instaurados na JUFAM no período. A maioria destes não foram encaminhados para o SERAV, em virtude da presença de técnicos/as durante um determinado intervalo de tempo, lotados diretamente na JUFAM. Outra questão é que nesta fase o Serviço de Pesquisa estava inativo, o que impossibilitou uma catalogação e pesquisa de todos esses casos, como nos informou a responsável pelo Serviço de Pesquisa do NUPS/SERAV.

O manuseio das pastas de acompanhamento dos processos identificadas para a análise, revelou de início um número substantivo de registros incompletos, em diferentes campos do formulário de registro das informações. Assim do total de 61 pastas, 23, ou seja, 37,7\% do total estavam incompletas e/ou apresentavam seções completamente em branco. Afora os prejuízos para o estudo, esse fato trouxe um dado importante à pesquisa. Questionados acerca desse fato, técnicos/as entrevistados/as indicaram entre os principais motivos para as pastas estarem completas: a ausência de uma das partes a muitos ou a todos os atendimentos previamente agendados pelo NUPS/SERAV (após o encaminhamento do JUFAM), além do acúmulo de serviços que impediu de preencherem integralmente o roteiro proposto na pasta. Acúmulo de serviço ocorrido com a promulgação da Lei no . 
11.340/2006, quando o setor passou a atender a $1^{\text {a }}$ Vara do Juizado de Violência Doméstica e Familiar contra a Mulher de Brasília, além de casos provindos de outros Juizados.

A consulta foi dificultada também pelo preenchimento das questões sem o devido respeito à ordem e localização destas no roteiro proposto pela equipe de pesquisa. Fato que requereu cuidado especial no exame de todo o material. A única exceção sistemática observada nos relatórios foi quanto os dados de identificação da natureza do vínculo entre agressor e vítima impressos nas cópias dos termos de audiência inseridos nas pastas, e, portanto presentes nas 61 pastas.

Essa análise inicial dos relatórios revelou um grupo de 12 técnicos/as respondia como responsáveis pela maioria esmagadora dos atendimentos de mulheres vítimas de violência conjugal, pois estes atenderam $80 \%$ de todos os casos encaminhados pela JUFAM. Convidados/as a participarem da pesquisa, foi possível entrevistar dez desse/as profissionais, o que representa 83,33\% do total. A amostra não alcançou todo o universo, pois dois técnicos haviam se mudado de setor, quando do inicio da pesquisa.

Antes de passarmos aos dados obtidos na análise das pastas contextualizaremos historicamente o surgimento do Serviço de Atendimento às Famílias em Situação de Violência - SERAV, para no item seguinte apresentarmos o perfil dos/as profissionais entrevistados/as. Feito isso, se apresenta o perfil das mulheres atendidas e os serviços de atendimento às mulheres vítimas de violência conjugal, com os quais o SERAV se articula, segundo a perspectiva dos/as entrevistados/as.

\subsection{O Serviço de Atendimento às Famílias em Situação de Violência - SERAV do Tribunal de Justiça do Distrito Federal e Territórios - TJDFT}

As novas exigências trazidas pela Lei $\mathrm{n}^{\circ}$. 11.340/2006 se traduziram, no caso do Distrito Federal, na criação, em outubro de 2006, da $1^{\text {a }}$ Vara do Juizado de Violência Familiar e Doméstica contra a Mulher de Brasília, conhecida como JUFAM/Brasília ${ }^{3}$.

\footnotetext{
3 Vale ressaltar que, a Vara do Juizado de Violência Doméstica e Familiar contra a Mulher de Brasília do Tribunal de Justiça do Distrito Federal e Territórios - TJDFT atende a Circunscrição Especial Judiciária de Brasília - CEJB. Tal circunscrição abarca: Plano Piloto, Lago Sul, Lago Norte, Riacho Fundo I e II, Núcleo Bandeirante, Candagolândia, Guará I e II e Cruzeiro. Os demais casos de violência doméstica e familiar do
} 
Entre as inovações previstas na Lei, pode-se destacar o acompanhamento sistemático dos casos, por equipes multidisciplinares, que ficou, inicialmente, a cargo do Núcleo Psicossocial Forense - NUPS, instituído em maio de 2000, com a finalidade de prestar assessoramento de cunho psicossocial às Varas Criminais e Juizados Especiais Cíveis e Criminais - JECS e JECRIMS, do Distrito Federal e Territórios, que passaram a funcionar com a Lei $n^{\circ}$. 9.099/1995 ${ }^{4}$.

O NUPS foi criado pelos JECS com o objetivo de acelerar os casos que chegavam à justiça, melhorar a qualidade de vida da clientela, realizar uma intervenção psicossocial com objetivo de levar as partes envolvidas no processo a uma reflexão da situação e principalmente com a finalidade de evitar a recorrência dessas pessoas na justiça para resolver os seus problemas. E entre os casos encaminhados merece destaque os de violência doméstica e familiar contra a mulher (ANGELIM; DINIZ, 2006).

$\mathrm{O}$ atendimento oferecido pelo NUPS em processos referentes à violência incluía o acolhimento das pessoas (partes) que eram encaminhadas pelo juiz responsável pelo caso, atendimentos: individuais, familiares e de casais (os dois últimos procedimentos é somente quando houvesse necessidade para tal), realização de grupos e palestras temáticas, grupos focais, relatórios e pareceres sobre os casos para os juízes responsáveis pelos processos e também o encaminhamento das partes para outras instituições e serviços, principalmente aqueles existentes na rede pública. Os atendimentos e as coordenações dos grupos geralmente aconteciam, por uma dupla de profissionais, independentemente da área de formação, como foi constatado durante o período em que a pesquisadora estagiou no serviço e no decorrer do trabalho de campo.

O Serviço de Atendimento às Famílias em Situação de Violência - SERAV do Tribunal de Justiça do Distrito Federal e Territórios - TJDFT, foi instituído após a reorganização e posterior extinção do NUPS, que deu lugar, em julho de 2007, à Secretaria Psicossocial Judiciária -

Distrito Federal deverão ser de responsabilidade de sua respectiva circunscrição, com procedimentos especiais nos Juizados Especiais Criminais de cada localidade (GHESTI; MOURA; ROQUE, 2006).

${ }^{4}$ Considerada um avanço na legislação brasileira referente à violência contra a mulher, à referida lei possibilitou a punição de tais práticas. Ao inserir tal forma de violência entre os crimes de menor poder ofensivo e, portanto passível de conferir ao autor, pena máxima de dois (2) anos. Na prática, o que se constatou em casos envolvendo a violência contra a mulher, foi o estabelecimento quase exclusivo de penas brandas como o pagamento de cestas básicas, de multas e/ou a prestação de serviços à comunidade. (CAVALCANTI, 2007). 
SEPSI, diretamente vinculada a Presidência do TJDFT e responsável por oferecer atendimento multidisciplinar em processos encaminhados pela da JUFAM e pelos Juizados Especiais Cíveis e Criminais - JECS e JECRIMS, baseados nos artigos da Lei 9.099 de 1995.

A equipe multidisciplinar do SERAV tem a competência de fornecer subsídios ao juiz além de atender as partes envolvidas, com ações de orientação, encaminhamento e prevenção e outras consideradas necessárias.

A respeito desse processo, no âmbito do DF, Roque, Ghesti e Moura (2006) destacaram:

Neste início de funcionamento do JUFAM/Brasília, consideramos que uma condição de trabalho que tem sido bastante propícia ao cumprimento do atendimento preconizado pela nova lei tem sido a circularidade da comunicação entre todos os membros da equipe multiprofissional (Juíza, Promotor, Defensores Públicos, Psicólogos e Assistentes Sociais), ao lado dos funcionários do Cartório e da Assessoria Jurídica e dos estagiários de diversas áreas (GHESTI; ROQUE; MOURA, 2006, p. 385).

Após historicizar a organização do atendimento multidisciplinar em processos envolvendo casos de violência doméstica e familiar contra a mulher no DF, até o surgimento do SERAV, apresentaremos no próximo item o perfil dos/as profissionais da equipe técnica do referido serviço, para assim apresentarmos os dados sobre as mulheres vítimas de violência conjugal.

\subsection{Perfil da Equipe Técnica do SERAV}

O perfil a seguir, refere-se aos 10 profissionais que foram entrevistados/as e que fazem parte da equipe técnica do Serviço de Atendimento às Famílias em Situação de Violência - SERAV. Estes profissionais são aqueles que mais atenderam os casos de violência contra a mulher no período delimitado para a pesquisa desta monografia: de novembro de 2006 à janeiro de 2007.

Sobre a já referida equipe, pode-se afirmar que esta é majoritariamente composta por mulheres (90\%), predomina, entre as/os integrantes da equipe técnica entrevistada, a faixa etária de 18 e 39 anos (60\% das pessoas entrevistadas), sendo que os outros $40 \%$ têm entre 40 e 60 anos. Psicólogas/os (oito) e assistentes sociais (duas) de formação, três dentre 
as pessoas entrevistadas (ou 30\% do total), fizeram mestrado - duas na área da educação e uma em psicologia clínica, e nove possuem título de especialista, destacando-se a formação em terapia familiar (três), terapia comunitária (três) e psicodrama (dois). (Vide roteiro no Anexo III).

Lotados/as originalmente no NUPS, todos/as os/as entrevistados/as estão no SERAV há mais de 04 anos, sendo que a temática da violência, já havia sido objeto de trabalho anteriormente, para 70\% desses/as; sempre, no âmbito do judiciário.

Os dados referentes à (s) capacitação (s) nos últimos 5 anos revelam uma média de duas capacitações por profissional, nesse período, destacando-se em termos de conteúdo as temáticas de família (80\%), gênero (60\%) e em terceiro lugar, ao lado de saúde, a Lei Maria da Penha (30\%). Vale assinalar que as temáticas da assistência, da segurança pública, da gestão pública e o Plano Nacional de Políticas para as Mulheres - PNPM, embora apresentados dentre as opções pela pesquisadora, não foram mencionadas por nenhum/a dos/as técnicos/as.

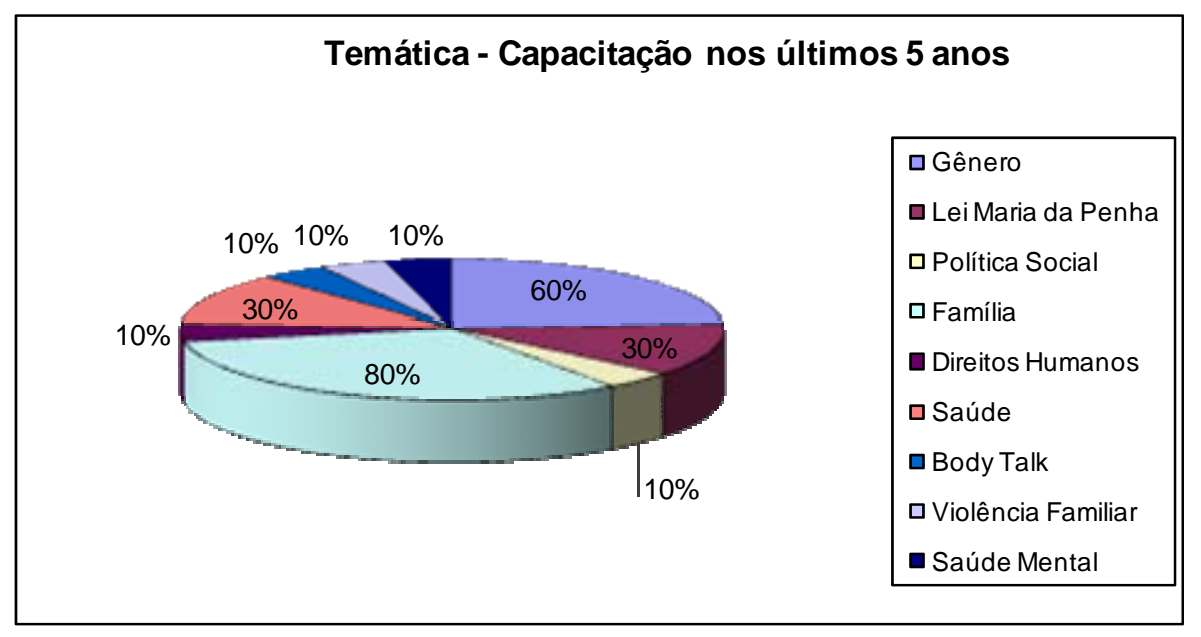

Os/as entrevistados foram solicitados a indicar três alternativas adotadas em atendimento dos casos de violência conjugal, durante o período mencionado (novembro de 2006 á janeiro de 2007). Dos/as entrevistados/as 100\% respondeu ter realizado atendimento de casal ou ex-casal, 80\% afirmou ter encaminhado tanto a mulher como o agressor (marido ou companheiro, e alguns casos estavam separados durante os atendimentos) para outras instituições e serviços, 60\% realizou atendimentos individuais com as partes, 60\% 
afirmou ter encaminhado uma das partes ou ambas para grupos desenvolvidos no próprio SERAV, e apenas 1 dos/as entrevistados afirmou adotar o atendimentos familiar como um dos seus principais procedimentos no acompanhamento de casos de violência conjugal.

No próximo item deste capítulo apresentaremos o perfil socioeconômico e cultural das mulheres vítimas de violência conjugal e a tipificação dos casos destas, que foram acompanhadas pelas/os técnicos/as do Núcleo Psicossocial Forense - NUPS/ Serviço de Atendimento às Famílias em situação de Violência - SERAV, participantes da pesquisa, a partir da análise dos dados obtidos nas pastas de acompanhamento individual.

\subsection{O perfil socioeconômico e cultural e a tipificação da violência das mulheres vítimas de violência conjugal atendidas no NUPS/SERAV do TJDFT}

A partir das informações disponíveis nos relatórios e nas pastas de acompanhamento buscamos traçar um perfil socioeconômico e cultural das 61 mulheres vítimas de violência acompanhadas pelo SERAV/NUPS. Mas antes de traçar tal perfil devemos apresentar brevemente alguns dados obtidos com análise da tipificação da violência.

Sobre a tipificação podemos afirmar que 33 dos 61 , ou seja, $54 \%$ se referiam que à violência conjugal. A junção dos dados referentes à violência conjugal com aqueles de violência perpetrada contra ex-companheiras ou ex-esposas, que representa a mulher com que o autor viveu uma relação de conjugalidade e união, sem necessariamente terem uma relação formal estabelecida (DIEHL, 2002), faz com a porcentagem de processos suba para aproximadamente $82 \%$.

Assim embora não referidas as relações conjugais strictu senso, em sua maioria os casos analisados referiam-se à violência em relações afetivo-sexuais entre: 17 de excônjuges (28\%), 08 de ex-namorados (13\%) e 02 de parceiros extra-conjugais (3\%). Sendo que somente 01 ( $2 \%$ do total de 61 ) dos casos envolvia irmãos.

Com base nestes dados iniciais sobre a tipificação apresentamos o perfil socioeconômico e cultural das mulheres vítimas de violência conjugal, que será iniciada com os dados sobre a faixa etária. Sobre este assunto foi possível verificar que maioria das mulheres cujas pastas, continha essa informação, possuía entre 18 e 39 anos (46 mulheres 
ou 83,6\% do total dos casos). Destas 46 mulheres, quase a metade, (22) eram vítimas de violência conjugal. Vale ressaltar que a questão da faixa etária estava respondida em 55 (cinqüenta e cinco) pastas.

Em se tratando de estado civil, cabe destacar inicialmente, que se optou nesta pesquisa por utilizar as delimitações do estado civil e da situação conjugal contempladas no roteiro do SERAV, que distingue entre aqueles casais unidos legalmente daqueles unidos de fato. Na tabela a seguir estão expostos cada um dos dados coletados e analisados.

Tabela 1 - Estado civil (atual)

\begin{tabular}{lcc} 
Estado Civil & $\begin{array}{l}\text { Mulheres vítimas de } \\
\text { violência/ geral }\end{array}$ & $\begin{array}{l}\text { Mulheres vítimas } \\
\text { de violência } \\
\text { conjugal }\end{array}$ \\
\hline Solteira. & 19 & 6 \\
Casada. & 7 & 7 \\
Separada de fato. & 5 & 3 \\
Separada/ judicialmente. & 2 & 0 \\
Divorciada. & 2 & 0 \\
Concubinato. & 13 & 12 \\
Viúva & 0 & 0 \\
\hline Total de dados preenchidos & 50 & 28
\end{tabular}

Ainda sobre o estado civil podemos destacar que no interior das pastas percebemos que um total de 50 haviam este item devidamente preenchido. E entre os dados constatamos que as mulheres vítimas de violência conjugal são as que mais vivem uma relação de concubinato, ou seja, elas não são casadas legalmente com os seus companheiros. Tais mulheres representam um total de 42\% (12), das 28 mulheres que sofrem violência conjugal e que tinham este dado inserido na pasta de acompanhamento. Vale destacar que este dado confirma a teoria de Diehl (2002), de que a conjugalidade de um casal independe do fato de haver um vínculo ou contrato formal estabelecido entre estes, ou seja, não há necessidade de ser casado legalmente.

Quanto à naturalidade de nascimento (local onde nasceram) das mulheres vítimas de violência doméstica e familiar, dentre as 45 pastas cuja informação estava disponível, 42\% (19) afirmaram ter nascido no Distrito Federal - DF. As outras 26 são naturais de 
outros estados, sendo que 14 de estados nordestinos, o que representa mais ou menos 54\% do total de casos, 8 (31\%) nasceram em algum estado da região sudeste e 4 (15\%) nasceram no norte do país.

Em relação à questão da moradia das mulheres vítimas de violência no Distrito Federal, dentre as 59 com informação disponível, apenas oito residiam em locais socioeconomicamente mais valorizados: Plano Piloto (Asa Sul e Asa Norte), Lago Sul, Lago Norte e Sudoeste. As outras 51 mulheres declararam residir em cidades satélites, e representam 86\% do total. Ou seja, embora em menor proporção é possível constatar que a violência apresenta-se enraizada em todas as camadas da sociedade (SANTOS, 1999). Deve-se destacar que os dados empíricos apontam para uma relação entre menor condição financeira e violência, assim como afirmado por Saul (apud, SANTOS, 1999), para quem a violência está relacionada à miséria, ao processo de modernização e também a precarização do emprego.

Ainda sobre a questão da moradia, devemos analisar a situação de moradia destas mulheres. Esta questão foi elaborada seguindo oito alternativas que estão dispostas na quarta tabela deste item. Assim analisamos que das 47 pastas respondidas, 26 eram de mulheres vítimas de violência conjugal, e descobrimos que 53\% dessas residem em casa própria.

Em relação ao grau de instrução pode-se destacar a quantidade de mulheres que possuem somente até o ensino fundamental. Nesta questão tinham 44 pastas respondidas, e dentre estas 50\% (22 pastas) eram de mulheres que concluíram até o ensino fundamental (antiga $8^{a}$ série). E 15 pastas (do universo de 22) refere-se as mulheres que sofrem violência de seus cônjuges, ou seja, mais de 68\% do total de 22.

A situação ocupacional e de vínculo empregatício das mulheres encontrada nas pastas de acompanhamento merecem ser destacadas, pois vão de encontro às pesquisas que abordam o tema. Das 52 pastas com resposta sobre situação ocupacional somente 12 eram de mulheres desempregadas, $23 \%$ do total, sendo que destas 8, vítimas de violência conjugal. Ainda sobre aquelas que se declararam desempregadas, 11 informaram estar nessa situação há menos de (um) ano. 
As mulheres empregadas totalizam 25, o que representa $47 \%$ das 52, as vítimas de violência conjugal são 14. Vale destacar que do total de mulheres empregadas, pouco mais de 50\% não possuem nenhum tipo de vínculo empregatício (13 mulheres).

Os dados acima contrariam, portanto o argumento de que a dependência econômica é o principal motivo para que a mulher vítima de violência doméstica e familiar permaneça durante muito tempo em relações conjugais violentas. A violência conjugal é permeada por inúmeros fatores não sendo a renda ou a ausência, o único determinante para a sua perpetuação. Muitas vezes os fatores que levam a relações conjugais violentas não podem ser mensurados de forma direta porque vários são os símbolos que as envolvem (BOURDIEU, 1999).

A situação ocupacional das mulheres está no gráfico abaixo discriminada.

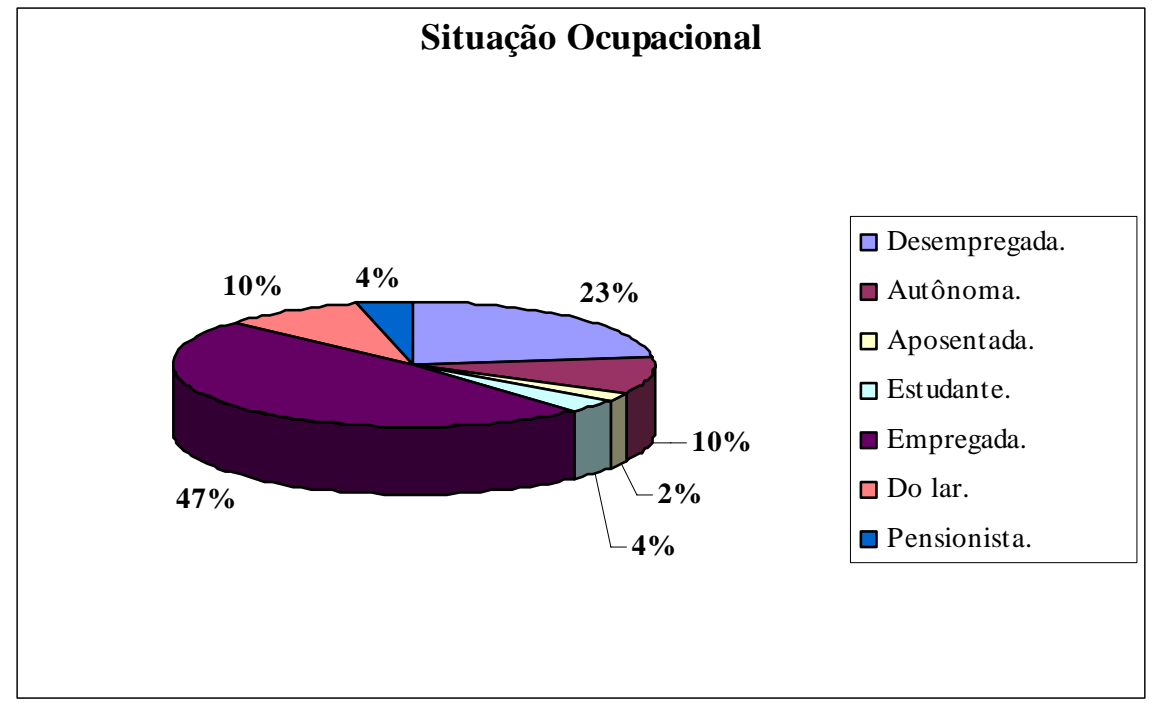

Quanto à renda pessoal e familiar das mulheres se apresenta na tabela 2 informações sobre a renda pessoal em salários mínimos, das 39 mulheres cujas pastas continham tal informação. Pode-se inferir com a análise desta tabela que 56,4\% das mulheres empregadas recebem de 1 a 3 salários mínimos, e destas 12 são mulheres vítimas de violência conjugal. 


\section{Tabela 2 - Renda Pessoal (em salários mínimos)}

\begin{tabular}{lcc} 
Salários Mínimos & $\begin{array}{c}\text { Mulheres vítimas de } \\
\text { violência/ geral }\end{array}$ & $\begin{array}{c}\text { Mulheres vítimas de } \\
\text { violência conjugal }\end{array}$ \\
\hline Menos de um salário & $\mathbf{5}$ & $\mathbf{4}$ \\
De 1 a 3 salários & $\mathbf{2 2}$ & $\mathbf{1 2}$ \\
De 4 a 8 salários & $\mathbf{1 0}$ & $\mathbf{5}$ \\
$\begin{array}{l}\text { De 8 a 12salários } \\
\text { Acima de 12 salários }\end{array}$ & $\mathbf{1}$ & $\mathbf{0}$ \\
& $\mathbf{1}$ & $\mathbf{0}$ \\
\hline Total de dados & $\mathbf{3 9}$ & $\mathbf{2 1}$ \\
preenchidos & &
\end{tabular}

A análise da tabela acima põe em destaque também a presença de mulheres na faixa de 4 a 8 salários mínimos: elas representam aproximadamente $26 \%$ da amostra de 39 mulheres, sendo que 5 delas são vítimas de violência conjugal. Mas deve-se destacar que se levarmos em conta as 61 pastas da amostra da pesquisa, as 39 sobre a renda pessoal representam $64 \%$ do total.

Sobre a renda familiar contatamos que a questão referente à mesma estava devidamente respondida em exatamente 46 pastas, e destas 27 são sobre a violência na conjugalidade, representando assim 59\% da amostra da referida pergunta. Deve-se destacar que o dado que sobressaiu sobre as renda familiar foi que 23 (50\% das 46 famílias) vivem com renda entre 01 e 03 salários mínimos para uma média de quatro pessoas. Este último dado pode ser analisado segundo Santos (1999), que afirma que a desigual distribuição dos recursos econômicos e a crescente miséria da população estão intimamente com o fato da violência de maneira geral.

Os dados sobre a situação de saúde estavam disponíveis no que se refere aos homens e as mulheres. Das 61 pastas da amostra 44 tinha este dado preenchido sobre a situação de saúde das mulheres e, 57 sobre a saúde dos homens. O primeiro aspecto que destacamos é sobre a resposta de ambos os sexos, que mencionaram não possuir nenhuma forma de doença. Das 44 pastas das mulheres, 23 destas não mencionaram nenhuma doença, o que representa $52 \%$ do total. Vale ressaltar que das 23 , exatamente 14 são de 
mulheres vítimas de violência conjugal. Já das 57 pastas dos homens em apenas 12 não havia menção sobre doenças, e representa $21 \%$ da amostra. A análise dos dados em termos gerais nos permite reafirmar o que já foi mencionado por outras pesquisas, que possivelmente as mulheres cuidam mais da saúde do que os homens, por isso mais da metade não mencionaram nenhuma doença. Na tabela abaixo estão especificados estes e outros dados sobre a situação de saúde das mulheres e dos homens.

Tabela 3 - Situação de Saúde das Mulheres e dos Homens

\begin{tabular}{|c|c|c|c|c|}
\hline \multirow{3}{*}{ Doenças } & Mulheres & & Mulheres & \\
\hline & $\begin{array}{c}\text { vítimas de } \\
\text { violência/geral }\end{array}$ & $\begin{array}{c}\text { Homens/violência } \\
\text { geral }\end{array}$ & $\begin{array}{l}\text { vítimas de } \\
\text { violência }\end{array}$ & $\begin{array}{c}\text { Homens/violên } \\
\text { cia conjugal }\end{array}$ \\
\hline & & & conjugal & \\
\hline
\end{tabular}

\begin{tabular}{lcccc}
\hline $\begin{array}{l}\text { Abuso/dependência } \\
\text { de álcool }\end{array}$ & 3 & 24 & 14 \\
$\begin{array}{l}\text { Abuso/dependência } \\
\text { de drogas }\end{array}$ & 1 & 9 & 0 & 6 \\
Transtornos Mentais & 9 & & & \\
Cardiopatias & 0 & 2 & 5 & 2 \\
Hipertensão & 0 & 1 & 0 & 1 \\
Outras Doenças & 8 & 7 & 4 & 4 \\
Nenhuma & 23 & 12 & 14 & 6 \\
mencionada & & & & 34 \\
\hline Total de dados & 44 & 57 & 25 &
\end{tabular}

Baseados na tabela acima um outro aspecto que devemos ressaltar diz respeito aos transtornos mentais, que foi mencionado por 9 mulheres (5 vítimas de violência conjugal), e todos estes transtornos foram especificados pelo técnicos, e 6 deles referem-se a algum tipo de depressão, sendo os outros são: raciocínio lento, síndrome do pânico e convulsões. Infelizmente não podemos mensurar ao certo a ligação de tais doenças com a violência sofrida por estas mulheres. 
Deve-se destacar também que a situação de saúde dos homens estava informado em 57 o que significa que esta em 13 pastas a mais do que as mulheres, sendo 34 dos processos relacionados à violência na conjugalidade. O principal problema de saúde identificado entre os homens diz respeito ao abuso ou dependência do álcool e também de outras drogas.

Sobre o consumo de álcool, 33 homens declararam durante o no acompanhamento no NUPS/SERAV, que abusavam ou dependiam do álcool, o que representa $42 \%$ das 57 pastas. Compreendendo o álcool como uma droga (mesmo que lícita) e analisando o mesmo com as outras drogas (ilícitas) o percentual de homens que fazem uso de pelo menos uma droga sobe consideravelmente, pois 9 homens afirmaram que fazem uso, abusam ou dependem de alguma substância ilícita; e somados àqueles que consomem o álcool, atingem a porcentagem de $57 \%$.

Sobre o álcool deve-se destacar o fato de seu uso ser mencionado em vários casos, para justificar ações violentas principalmente aquelas praticadas contra as mulheres. Edwards (1999) afirma que o álcool não pode ser utilizado como justificativa para execução ou manutenção da violência:

Muitos estudos mostraram uma alta freqüência de embriaguez entre agressores violentos no momento do ato criminoso, mas isso não prova que a bebida causou o crime. As pessoas inclinadas à violência podem coincidentemente decidir beber, a bebida sendo um mero adjunto para situações e confrontações intrinsecamente perigosas, e o álcool pode ser usado como desculpa (EDWARDS, 1999, p.74-75).

Agora iremos mencionar questões relacionadas à vivência e a tipificação da violência para as mulheres, apreendidas nas informações existentes nas 61 pastas analisadas. Assim pode-se afirmar que a análise individual das pastas corrobora a necessidade de considerar a complexidade e múltiplas faces que conformam as relações de conjugalidade, para além da dimensão formal e/ou espacial que a caracteriza. Um dos relatórios examinados envolvendo violência conjugal, por exemplo, indica a retomada do casamento durante o acompanhamento no SERAV, enquanto outros 7 (sete) revelam a separação das partes, durante ou depois do acompanhamento no serviço. O que indica a separação como alternativa escolhida por 21,2\% do universo de 33 mulheres vítimas de violência conjugal. 
O tempo médio de duração dos relacionamentos conjugais foi outro aspecto observado. Para isso analisamos de maneira conjunta o tempo que a mulher viveu e se declarava ainda viver com o companheiro. Este dado estava preenchido em 70\% (43 pastas) do universo de 61 que representa o total da amostra.

O que chama a atenção nessa questão é o pouco tempo de convivência conjugal, observado na maioria dos casos analisados, 16 mulheres (37\% de 43 da relação conjugal ou ex-conjugal) responderam que conviveram (ou ainda convivem) com os companheiros entre 01 e 05 anos. Vale ressaltar que 9 entre estas mulheres afirmaram que ainda convivem maritalmente com os companheiros/maridos.

Os dados apresentados acima apontam em sentido bastante distinto, da realidade apontada nos estudos sobre as relações violentas longas e crônicas. Sobre tais estudos podemos observar o que defende a autora Fernanda Marques de Queiroz (2002), pois para ela existe uma vulnerabilidade maior da mulher vítima de violência doméstica e conjugal, e o rompimento do vínculo ou contrato com os agressores é muito difícil, pois as relações são mescladas por sentimentos, cumplicidade e afetividade. Devemos lembrar que todos os casos que foram analisados são sobre a Lei 11.340/2006 que é um novo marco na questão da violência contra a mulher.

A análise do material de pesquisa em relação à questão da reincidência da violência mostrou-se um fato que merece atenção, pois a reincidência da violência estava presente, ainda que nem sempre esta levasse a outra denúncia ${ }^{5}$. Dentre os 43 processos relatados, em 65\%, as mulheres afirmaram já haver acontecido outros episódios de violência, e, deste total, mais de 39\% (17 das 43) eram mulheres vítimas de violência conjugal.

A apresentação do perfil socioeconômico e cultural das mulheres vítimas de violência doméstica e familiar, e também de alguns dados sobre os homens indicam alguns tipos de serviços e instituições importantes para o atendimento das demandas indentificadas. No próximo item iremos focalizar as instituições de atendimento às mulheres vítimas de violência, existentes no Distrito Federal, identificadas na análise das pastas como os locais que o NUPS/SERAV mais encaminhou as pessoas envolvidas em

\footnotetext{
${ }^{5}$ Depoimento de técnica, durante entrevista.
} 
situação de violência doméstica e familiar, no período delimitado como amostra desta pesquisa.

\subsection{As instituições de defesa da mulher existentes no Distrito Federal mais acionadas pelo NUPS/SERAV}

No Distrito Federal - DF várias instituições trabalham com a temática da violência contra a mulher. Mas neste item no ateremos a apresentar as instituições, serviços e programas que possuem relação com o NUPS/SERAV, ou seja, aquelas que receberam encaminhamentos do serviço no período de novembro de 2006 a janeiro de 2007. Estas instituições foram conhecidas após a análise das 61 pastas, que se referem à amostra desta pesquisa, e também nas entrevistas realizadas com os/as técnicos/as do SERAV.

Constatou - se inicialmente que os procedimentos adotados pelo SERAV para encaminhamentos se referiam a quatro modalidades: somente mulher, somente homem, para ambos, e para a família (neste último o encaminhamento pode ser tanto para um membro da família quanto para toda essa).

De todos os 61 casos analisados na pesquisa constatamos que foram realizados 87 encaminhamentos, e estes foram bastante diversificados e realizados para instituições da saúde, assistência e também para o próprio judiciário, uma vez que o próprio NUPS/SERAV desenvolve atividades em grupos com as e os envolvidas/os, e tem como propósito principal o trabalho com questões relacionadas direta ou indiretamente com a temática da violência, como por exemplo, a temática de gênero, a resolução de conflitos, traição, ciúmes, entre outros temas.

O quadro a seguir mostra quais foram os principais encaminhamentos adotados para mulheres e os homens com o número de casos, tais encaminhamentos representam 71 (34 de mulheres e 37 de homens, discriminados dentre estes os de violência conjugal). Há também no quadro uma breve explicação sobre cada instituição. 
Quadro 1 - Instituição para onde os homens e as mulheres foram encaminhados/as

\begin{tabular}{|c|c|c|c|c|}
\hline Instituições/Serviços & $\begin{array}{c}\text { Mulheres } \\
\text { Vítimas de } \\
\text { violência/geral }\end{array}$ & $\begin{array}{l}\text { Homens/ } \\
\text { violência } \\
\text { geral }\end{array}$ & $\begin{array}{l}\text { Mulheres } \\
\text { vítimas de } \\
\text { violência } \\
\text { conjugal }\end{array}$ & $\begin{array}{l}\text { Homens/ } \\
\text { violência } \\
\text { conjugal }\end{array}$ \\
\hline $\begin{array}{l}\text { CAPS/AD Centro de } \\
\text { Atendimento Psicossocial } \\
\text { de Álcool e outras Drogas: } \\
\text { serviço público com foco na } \\
\text { redução de danos. }\end{array}$ & 2 & 9 & 2 & 6 \\
\hline $\begin{array}{l}\text { Conselho de Direitos da } \\
\text { Mulher - CDM: serviço } \\
\text { público com assistência } \\
\text { jurídica e atenção psicossocial. }\end{array}$ & 3 & 5 & 1 & 3 \\
\hline $\begin{array}{l}\text { Grupo de Mulheres que } \\
\text { Amam demais -MADA: } \\
\text { grupo de auto-ajuda }\end{array}$ & 2 & 0 & 1 & $\mathbf{0}$ \\
\hline $\begin{array}{l}\text { Grupos de Homens: } \\
\text { grupo de auto-ajuda. }\end{array}$ & 4 & 0 & 1 & $\mathbf{0}$ \\
\hline $\begin{array}{l}\text { Grupo do SERAV: grupos } \\
\text { para reflexões e discussões de } \\
\text { temas. }\end{array}$ & 14 & 12 & 8 & 4 \\
\hline $\begin{array}{l}\text { Programa de Alcoolismo e } \\
\text { outras Drogas do HUB: } \\
\text { serviço público e também com } \\
\text { foco na redução de danos. }\end{array}$ & 0 & 1 & 0 & 1 \\
\hline $\begin{array}{l}\text { Saúde Mental }- \text { São } \\
\text { Vicente de Paula e } \\
\text { Hospital de Base: para } \\
\text { avaliação e acompanhamentos } \\
\text { psiquiátricos. }\end{array}$ & 3 & 0 & 1 & 0 \\
\hline $\begin{array}{l}\text { Terapia Comunitária: } \\
\text { grupos terapêuticos e de } \\
\text { reflexão comunitários. }\end{array}$ & 3 & $\mathbf{0}$ & 3 & $\mathbf{0}$ \\
\hline $\begin{array}{lcr}\begin{array}{l}\text { Terapia } \\
\text { clínicas }\end{array} & \begin{array}{c}\text { Individual: } \\
\text { gratuitas }\end{array} & \text { em } \\
\text { finalidade } & \text { social. } & \\
\end{array}$ & 7 & 6 & 5 & 3 \\
\hline $\begin{array}{ll}\text { Total de dados } \\
\text { preenchidos }\end{array}$ & 34 & 37 & 21 & 18 \\
\hline
\end{tabular}

Dos 87 encaminhamentos constatou-se que 34 foram somente para a mulher, 39\% do total, e destes 21 para as vítimas de violência conjugal. Para os homens foram realizados 37 encaminhamentos, $43 \%$ de 87 , e 18 deles somente para os casos de violência na conjugalidade. Sobre os encaminhamentos conjuntos pode-se afirmar que 12 deles foram 
realizados para o casal nas situações em que estes ainda conviviam como cônjuges, o que representa $14 \%$ do total de 87 encaminhamentos. O outros 4 encaminhamentos foram realizados para filho/a de uma das partes ou do (ex) casal propriamente dito.

Os dados do quadro mostram que os grupos temáticos e de reflexão do SERAV foram os que mais receberam encaminhamento do próprio serviço, neste um total de 14 mulheres e 12 homens foram encaminhados, 26 do total de 87, o que representa aproximadamente $30 \%$ do total. Estes dados são muito importantes, pois pode traduzir dois fatos: o primeiro é que possivelmente existam poucos serviços que possuem uma metodologia semelhante com a que é desenvolvida pelo SERAV em seus grupos e o segundo é que o desconhecimento do SERAV sobre a existência desses serviços impeça tal articulação.

Outro dado que nos chama a atenção diz respeito aos encaminhamentos realizados para as terapias individuais, pois 13 foram realizados para esta forma de serviço. Dos 13, exatamente 7 para as mulheres, sendo que 71\% dessas são vítimas de violência conjugal, 5 do total de 7. Os outros 6 encaminhamentos foram para os homens, sendo que $50 \%$ foram para aqueles relacionados a violência entre cônjuges.

Os encaminhamentos para serviços que objetivam realizar reflexões e tratamentos sobre álcool e outras drogas com o foco na redução de danos (CAPS/AD no Guará e Programa do HUB), foram realizados principalmente para os homens, do total de 12 encaminhamentos, 10 foram para os homens, e representam mais de 83\% do total destes. Pode-se afirmar que tais dados de encaminhamentos vão ao encontro dos que foram apresentados no perfil socioeconômico e cultural dos homens envolvidos em situação de violência, na questão da situação de saúde dos mesmos, uma vez que 42 homens, 57\% da amostra de 57 pastas com dados disponíveis, declararam usar, abusar ou depender do álcool ou de alguma outra droga.

Outra informação que nos chama a atenção quando observamos os dados é que nenhum homem foi encaminhado para avaliação e/ou acompanhamento psiquiátrico, e o mesmo acontece com os encaminhamentos para a terapia comunitária. No caso das mulheres os encaminhamentos para serviços de saúde mental remete a situação de saúde das mesmas, onde o transtorno mental foi apontado por 9 mulheres. A terapia comunitária 
apareceu como um recurso utilizado mais para as mulheres do que para os homens sem que fosse possível identificar nas pastas ou nas entrevistas o motivo dessa tendência, e tal questão pode ser motivadora para pesquisas futuras.

Sobre os encaminhamentos para o Conselho de Direitos da Mulher - CDM, pode-se afirmar que aproximadamente 63\% foram realizados para os homens, 5 homens do total da amostra de 8 encaminhamentos realizados para este serviço. Houve também mais encaminhamento para os homens no que diz respeito a grupos de auto-ajuda, pois foram realizados 4 para os homens, e para os grupos de auto-ajuda de mulheres somente 2 encaminhamentos.

No próximo item apresentamos a opinião dos/as profissionais da equipe do NUPS/SERAV sobre as instituições que mais ajudaram a modificar a situação de violência vivida pelas mulheres vítimas de violência conjugal. E assim vamos apresentar brevemente qual é o serviço prestado por cada instituição, e após analisaremos a avaliação que tais técnicos/as fazem sobre as mesmas.

\subsection{As instituições identificadas pela equipe do NUPS/SERAV e suas contribuições para modificar a situação de violência.}

Neste item iremos destacar as instituições que segundo a opinião da equipe técnica do Serviço de Atendimento às Famílias em Situação de Violência - SERAV ajudaram a modificar e/ou eliminar a situação de violência conjugal vivida pelas mulheres, antes porém se procederá a uma breve caracterização das mesmas. Durante a realização da entrevista cada um dos/as 10 entrevistados/as tinha o direito de escolher as três principais instituições, mas nem todos/as profissionais escolheram as três principais. A seguir apresentamos as instituições mais mencionadas, com uma breve descrição das mesmas, para então apresentar e explicar as opiniões dos/as técnicos/as sobre as mesmas.

As instituições identificadas podem ser agrupadas em três áreas: saúde (Programa Margarida, Projeto Violeta, e Programas de Alcoolismo e outras drogas), terapêutica, psicológica e/ou de saúde mental (Grupos de Casal, Terapias Individuais e Terapias Comunitárias) e serviço de assistência e psicossocial (Conselho de Direitos da Mulher CDM). 
Perguntados/as acerca das instituições que ajudaram modificar a situação de violência conjugal os/as técnicos/as apontaram diferentes serviços/programas. O Programa Margarida e Projeto Violeta foram mencionados nesta pergunta por apenas um técnico. O Grupo de Casal foi apontado por 50\% dos/as entrevistados/as como mais importante para modificar/eliminar a situação de violência conjugal, a mesma porcentagem serve para o Conselho de Direitos da Mulher - CDM e para os Programas de Alcoolismo e outras Drogas (HUB e CAPS/AD - Guará). A Terapia Individual foi mencionada por três técnicos (30\% do total de 10 entrevistados) e a Terapia Comunitária foi citado por 2 entrevistados/as, 20\% do total da amostra. A seguir apresentamos e caracterizamos tais serviços.

- Centro de Atenção Psicossocial de Álcool de Drogas - CAPS/AD e Programa de Alcoolismo e outras Drogas do Hospital Universitário de Brasília - HUB: (Estes serviços serão analisados conjuntamente, pois possuem semelhante nas suas metodologia e finalidade). Tais serviços são públicos, e visam realizar o acompanhamento, reflexão e apoio aos usuários ou dependentes de álcool. O foco principal é o trabalho com a redução de danos, ou seja, o trabalho não objetiva a abstinência de nenhuma droga, mas a redução gradual da mesma para diminuir ou evitar danos físicos, psíquicos e até mesmo sociais ocasionados pelas drogas. $\mathrm{O}$ trabalho do CAPS/AD foi motivo de destaca por realizar um "Trabalho multidisciplinar”, e propiciar a modificação da situação de violência conjugal na medida em que "Ajuda a controlar a compulsão de forma a aflorarem os mecanismos geradores da compulsão e dos comportamentos decorrentes, como a violência”, e se constitui num “Espaço de tratamento especializado para uso abusivo de substâncias que terminam favorecendo os conflitos conjugais”. O Programa do HUB foi avaliado positivamente em virtude da metodologia utilizada no “Tratamento da dependência química e redução do uso abusivo”, que favorece as mudanças necessárias com relação à questão do uso abusivo de álcool e/ou outras drogas, mas embora não trate da questão específica da violência entre cônjuges: “Apoiar, orientar e tratar questões do álcool e outras drogas. E viabilizar 
um espaço de reflexão com vistas à responsabilização e fortalecimento individual para alcance das mudanças necessárias”.

- Conselho de Direitos da Mulher - CDM: (Serviço governamental, e possui serviços vinculados à assistência, ao serviço jurídico e psicossocial; desenvolve atividades individuais, grupais e de casais tanto com os homens quanto com as mulheres). As vantagens dos serviços ofertados pelo CDM foram mencionadas pelos/as entrevistados/as a primeira foi como o serviço em geral "Gratuidade, o trabalho grupal e o acompanhamento individual dos homens”, outros avaliaram que a principal vantagem era de “Aprofundar questões individuais e relacionais”. Outra citação diz respeito à modificação da violência propriamente dita: “O grupo reflexivo para os homens e o atendimento familiar contribuiu muito para superar as relações de violência”.

- Grupos de Casal: (Estes grupos são desenvolvidos por inúmeras serviços/instituições, e podem ser de natureza pública, social ou privada. O trabalho é terapêutico e realizado em grupo com casais. Geralmente os casais encaminhados para estes serviços objetivam continuar as suas relações conjugais, mas necessitam de um acompanhamento e de ajuda para modificar e/ou eliminar as situações de violências vividas). De acordo com um dos/as profissionais entrevistados/as o grupo de casal ajudou a modificar a situação de violência conjugal, “(...) pelo acompanhamento da evolução da dinâmica, do padrão da violência e oportunidade de aprofundar nas reflexões”. Tais grupos são considerados importantes ainda por “Ajudas quando o casal tinha vontade/demanda para o trabalho”, e por significarem “A oportunidade das partes terem intervenções com profissionais fora do contexto da justiça”. Se reconheceu também a importância destes grupos na reflexão sobre a responsabilidade tanto do homem quanto da mulher em seus relacionamentos. Nas palavras de um/a entrevistado/a tais grupos são validos porque "Ajuda a promover a compreensão da dinâmica da violência. Desenvolver habilidades para lidar com os conflitos de maneira não violenta, incluindo a leitura de gênero”, e outro afirma que estes são “(...) espaço de 
acolhimento e reflexão sobre a construção do relacionamento e a sua responsabilidade no desenvolvimento deste relacionamento”.

- Programa Margarida e Projeto Violeta: (Embora sem constar qualquer registro nas pastas de acompanhamento referente aos Programas Margaridas e Violeta, uma das pessoas entrevistadas os mencionou dentre aqueles considerados como importantes na modificação das situações de violência conjugal. Tais serviços desenvolvem ações semelhantes e estão vinculados ao campo da saúde, atendem: mulheres, homens e demais familiares quando há a necessidade. Entre a metodologia desenvolvida por tais serviços pode-se destacar: a triagem dos casos, o trabalho em grupo e o acompanhamento social, psicológico e médico). Sobre a importância de tais serviços na modificação da violência a profissional informou que estas objetivam “Ampliar a rede de atendimento às famílias, favorecendo o acesso à saúde e melhoria das relações”.

- Terapia Comunitária: (Este serviço oferece terapia em grupo, onde são abordados variados temas escolhidos pelos próprios membros deste com a coordenação de geralmente um ou dois profissionais, tais grupos são gratuitos e acontece em várias cidades satélites. Os grupos são mistos e formados por pessoas de diferentes idades, um dos objetivos do grupo é ampliar a rede social do individuo) A principal vantagem da Terapia Comunitária foi assim definida por um/a dos/as profissionais: “formar rede social que possa dar assistência para as mudanças necessárias, a partir da própria responsabilização e da elevação da autoestima”.

- Terapia Individual: (Estas terapias são desenvolvidas principalmente em clínicas escolas (universidades) gratuitas, ou daquelas com finalidade social, em que há uma avaliação socioeconômica para estipular o valor das sessões. Tais terapias estimulam as reflexões individuais e relacionais, e nestas podem ser adotadas inúmeras técnicas): As terapias individuais foram apontadas como vantajosas nos casos de violência conjugal em virtude de: “Produzir reflexões sobre a própria responsabilidade na situação conflituosa vivida e sobre as possibilidades de mudança”, e também permitir a "Reparação emocional, tratamento do stress pós- 
traumático, resgate da auto-estima da mulher e possibilidade de reflexão profunda por parte dos homens”.

No item seguinte vamos apresentar quais foram os principais procedimentos adotados pelo Serviço de Atendimento às Famílias em Situação de Violência - SERAV no atendimento dos casos de violência conjugal. Os procedimentos adotados referem-se à articulação dos/as técnicos/as do SERAV com as outras instituições e serviços do Distrito Federal que atendem tanto a mulher vítima de violência quanto os agressores.

\subsection{Os procedimentos utilizados pelos/as técnicos/as do SERAV para acionar os serviços/instituições.}

Indagadas/os sobre os procedimentos utilizados para contato e articulação com as instituições e serviços, 90\% das/os entrevistadas/os afirmaram utilizar o formulário próprio existente no SERAV, para encaminhamento aos serviços/instituições, entregando-o diretamente às próprias mulheres para que estas levassem à instituição ou serviço. O que revelou que, nesses casos, o primeiro contato das mulheres com tais instituições, conta com a intermediação do serviço mediante o envio do referido formulário.

O uso do contato telefônico como forma de articulação com outros serviços e instituições foi apontado por 7 dos 10 técnicos/as. Dois (2) afirmaram que utilizaram um relatório próprio do caso para encaminhamento das partes, 1 (10\% do total dos 10) pessoa entrevistada afirmou que encaminhou por meio de um ofício direcionado à instituição/serviços, enquanto outra a afirmou ter entrado em contato pessoal com o programa/instituição.

O procedimento adotado para o encaminhamento a instituições/serviços é considerado satisfatório por 50\% dos/as técnicos/as entrevistados/as; 30\% consideraram insatisfatório; uma técnica considera o procedimento adotado por ela como semisatisfatório e um/a técnico/a não soube responder tal questão. Dos/as técnicos/as que consideram o procedimento adotado insatisfatório, dois indicaram o contato pessoal com a instituição/programa como mais satisfatório e um indicou a elaboração de um relatório especifico para a instituição que receberá o encaminhamento como alternativa satisfatória. 
Opinião partilhada pela/o técnica/o que classificou o procedimento adotado como semisatisfatório.

Ainda sobre os procedimentos utilizados para articulação com instituições/serviços foi perguntado as pessoas da equipe técnica entrevistadas sobre o retorno recebido dos programas/instittuições para onde se encaminha a mulher vítima de violência conjugal, ou então de seu (ex) marido ou (ex) companheiro.

80\% dos/as técnicos/as afirmaram ter recebido alguma forma de retorno, e 20\% não receberam retorno de nenhuma espécie. Dos que receberam alguma forma de retorno: 50\% declararam que foi por meio de um formulário próprio da instituição/serviço, 40\% por contato telefônico (sem nenhum documento formal), 20\% recebeu um formulário próprio do acompanhamento realizado pelo serviço/instituição, um/a recebeu um oficio especifico e um/a técnico recebeu um atestado de comparecimento após finalização do caso na instituição.

A seguir apresentaremos a análise feita pelos/as técnicos/as do SERAV sobre os serviços que atendem as mulheres vítimas de violência conjugal no Distrito Federal. Tal análise é permeada por críticas ou sugestões sobre o trabalho e a metodologia adotada por estes.

\subsection{Avaliação dos serviços de atendimento às mulheres vítimas de violência conjugal do Distrito Federal: a constituição de uma rede?}

$\mathrm{Na}$ entrevista com os/as técnicos/as se indagou sobre sua avaliação dos serviços e instituições que atendem as mulheres vítimas de violência, solicitando-lhes indicar pontos críticos e sugestões para a melhoria. A questão foi respondida por $70 \%$ dos/as entrevistados/as. As respostas dos/as profissionais em sua maioria indicaram como questões críticas: a quantidade insuficiente de serviços/instituições para o atendimento da problemática da violência contra a mulher e a pouca articulação entre tais serviços e a justiça, apesar dos retornos recebidos por tais serviços, os/as técnicos/as consideram estes incipientes.

Sobre a questão do retorno incipiente recebido os/as entrevistados/as incluíram entre as sugestões para sanar o problema o estabelecimento de um processo continuado de 
diálogo entre as instituições "Sugiro que estes serviços possam dar um retorno periódico dos casos para nós. Pode ser semestral, por escrito em breves relatórios a respeito da presença da violência”.

A falta de uma articulação orgânica entre os serviços/instituições, ou mesmo da necessidade desta, repercute não só na falta de retorno, mas como assinalado em uma entrevista, se mostra na medida em que "Os serviços não buscam entrar em contato com a gente, fica uma coisa fragmentada. Os objetivos que orientaram o encaminhamento do SERAV, nem sempre eram levados em conta pelos serviços”.

A questão da pequena quantidade de serviços para atender a questão da violência ou para atendimento de algum fator de risco relacionado a esta, foi mencionado por 20\% dos/as técnicos/as. Um/a profissional entrevistado sinalizou, nesse sentido a importância do trabalho dos CAPS-AD e a importância de "que o CAPS-AD possa se expandir por mais cidades em Brasília e que haja, também mais oferta de terapias e clínicas sociais”. Em outra entrevista destacou-se a necessidade de "Ampliar o quadro de funcionários para reduzir a espera”, destacando ainda a imprescindibilidade de um “Trabalho mais integrado com outras instituições de uma determinada comunidade”.

Perguntados/as sobre a questão da articulação dos serviços, instituições e programas que atendem os casos de violência conjugal, além de outras formas de violência, dois (2) técnicos/as apresentaram sugestões e um/a expressou críticas ao processo. No primeiro caso, se indicou a importância de “contato mais próximo dos profissionais da rede com a justiça”, “ampliar a rede de atendimento não só numericamente, mas estabelecendose em todas as satélites”. Já a crítica indicou a “falta de maior articulação entre serviços e instituições, o que dificulta o conhecimento dos programas dessas instituições. Em algumas situações sabe-se sobre a existência dos programas, mas não se sabe sobre sua metodologia”.

Assim no que se refere à articulação dos serviços e a constituição de uma da rede os/as técnicos/as do SERAV deixam claro a insuficiência e a importância de se articular efetivamente uma rede de atendimento (diversos programas, projetos, organizações governamentais e não governamentais e serviços), até mesmo para uma maior clareza nos atendimentos e nas informações. 
Na problemática da violência contra a mulher a articulação de rede torna-se realmente necessária, para que seja alcançada uma operacionalização ampla das conquistas que foram adquiridas com a Lei Maria da Penha (GHESTI, ROQUE e LOBÃO, 2006). Tal questão também é abordada Carreira e Pandjiarjian (2003) que defendem uma construção de uma rede para o enfrentamento das formas de violência contra a mulher.

Percebemos assim que em algumas situações não há uma maior comunicação entre a justiça e os serviços (vice-versa) que atendem as mulheres vítimas de violência, e tal fato torna-se um enorme empecilho para que o acompanhamento dos casos realmente se concretize, e que os direitos sejam de fato alcançados. 


\section{Considerações Finais}

A questão da violência doméstica e familiar contra a mulher ocupa há várias décadas posição de destaque no debate cientifico e acadêmico. E a conceitualização de tal forma de violência torna-se um trabalho bastante complicado, uma vez que a mesma está inserida em diferentes contextos e pode acontecer das mais inúmeras formas. Neste trabalho buscou-se uma aproximação conceitual do termo violência, e mais precisamente dos termos violência de gênero e violência conjugal.

A violência conjugal é uma das formas de violência doméstica e familiar, e esta foi escolhida como foco central do trabalho após o levantamento sistemático e análise dos casos acompanhados pelo Serviço de Atendimento às Famílias em Situação de Violência SERAV. Tais casos são os inaugurais da Vara do Juizado de Violência Doméstica e Familiar contra a Mulher de Brasília - JUFAM, depois da promulgação da Lei $\mathrm{n}^{\circ}$. 11.340/2006, e que ficou conhecida como Lei Maria da Penha. A lei mencionada anteriormente é fruto da luta de grupos de mulheres e da sociedade civil organizada em prol dos direitos das mulheres, principalmente sobre a temática da violência.

Com as primeiras evidências levantadas a partir dos dado desta monografia, constatamos que mais da metade dos casos inaugurais, dentro da amostra estabelecida para a pesquisa, encaminhados do JUFAM para o SERAV eram sobre a questão da violência conjugal. E que quando estes dados foram analisados junto com aqueles em que o autor viveu alguma forma de conjugalidade com a mulher, a porcentagem passou dos oitenta por cento.

Uma outra questão recorrente ao debate sobre a violência cometida contra a mulher, diz respeito ao fato destas dependerem economicamente de seus maridos ou companheiros, e isto levar as mesmas a 'manter' e não desvincularem de seus relacionamentos. No entanto, em nossa pesquisa verifica-se que a maioria das mulheres estão empregadas, e que a dependência econômica pode não significar o principal motivo para a manutenção de suas relações conjugais.

O foco central desta monografia consistiu em conhecer quais foram os serviços identificados e acionados pela equipe técnica do SERAV para o atendimento das mulheres 
vítimas de violência conjugal. Assim, depois do conhecimento e análise de dados verificamos que tal equipe, após acompanhamento inicial das partes, encaminha os casos para alguns serviços de atendimento das mulheres vítimas de violência conjugal ou para outros serviços que atendam os agressores destas mulheres.

Os próprios/as técnicos/as do SERAV apresentaram críticas e sugestões sobre a quantidade de serviços que trabalham com as temáticas da violência e de temas correlatos, como por exemplo, a questão do alcoolismo que é apontado como algo que potencializa ações violentas de alguns agressores contra as mulheres. Outras sugestões foram para que se criassem mais serviços nas cidades satélites, mas sobre este assunto os/as técnicos/as sugeriram a criação de serviços já conhecidos por eles, e com os devidos 'resultados' comprovados. Apesar de tais profissionais mencionarem a necessidade da articulação de redes, não há nenhuma sugestão destes de como esta deve ser realizada.

As entrevistas realizadas revelaram que poucos serviços do Distrito Federal receberam encaminhamento do SERAV, o que sinaliza a inexistência de uma rede que vincule organicamente a justiça e as demais instituições, e não necessariamente a existência de poucos serviços como tínhamos deduzido com a hipótese proposta para esta monografia.

Compreendemos assim que a articulação de uma rede integrada sobre a temática da violência é muito difícil entre poucos serviços, e pode ser ainda mais complicada ser for realizada entre muitos. Mas esta não é uma tarefa impossível se existir um contato mínimo entre tais instituições, e se estas proporem conhecer o serviço que é desenvolvido por cada uma, até mesmo para que se possam alcançar as principais inovações estipuladas pela Lei $\mathrm{n}^{\circ}$. 11.340 no que tange ao atendimento integrado as mulheres vítimas de violência domestica e familiar, e também no atendimento dos agressores.

Assim os principais achados dessa pesquisa trazem dados importantes e significativos sobre o debate da questão da violência conjugal contra a mulher de Brasília, e também dos serviços que atendem estas e os agressores, mas apontam para a necessidade de estudos futuros nestas temáticas. Pois só depois de mais estudos poderemos avançar em alguns temas que foram abordados nesta monografia de forma exploratória. 


\title{
Referências Bibliográficas
}

\author{
ALVAREZ, Sônia E. Encontrando os Feminismos Latino-Americanos e Caribenhos. \\ In: Revista Estudos Feministas. Florianópolis, Santa Catarina, 2003. pp. 541 - 574.
}

ALVES, Branca Moreira; PITANGUY, Jacqueline. O que é feminismo. São Paulo: Ed. Brasiliense, 1981. pp. 2 - 30.

ANGELIM, Fábio; DINIZ, Gláucia. Núcleo Psicossocial: o Desafio da Psicologia Cínica no Entrecruzamento com Direito, Estado e Cidadania. In: Novos Paradigmas na Justiça Criminal: relatos de experiências do Núcleo Psicossocial Forense do TJDFT. Brasília: Ed. TJDFT, 2006. pp. 35 - 50.

BANDEIRA, Lourdes; SUÁREZ Mireya. Introdução à violência, gênero e crime no Distrito Federal. In: Violência, gênero e crime no Distrito Federal. Brasília: Paralelo 15, Editora Universidade de Brasília, 1999. pp. 13 - 19.

BOURDIEU, Pierre. Dominação masculina (a). Rio de Janeiro: Bertrand Brasil, 1999.158p.

BOURDIEU, Pierre. Sobre o poder simbólico. In: O poder simbólico. 8.ed. Rio de Janeiro: Bertrand Brasil, 2005. pp. 07 - 16.

BRASIL. Lei No . 9.099. Dispõe sobre os Juizados Especiais Cíveis e Criminais e dá outras providências. Diário Oficial da União 1995; 26 de setembro de 1995. Disponível em <http://www. planalto.gov.br/CCVIL/_03/leis/19099.htm>. Acesso em: 10 de setembro de 2007.

BRASIL. Lei No $\mathbf{1 1 . 3 4 0 ~ " L e i ~ M a r i a ~ d a ~ P e n h a ” . ~ C r i a ~ m e c a n i s m o s ~ p a r a ~ c o i b i r ~ a ~ v i o l e ̂ n c i a ~}$ doméstica e familiar contra a mulher. Diário Oficial da União 2006. 22 de agosto de 2006. Disponível em <http://www. planalto.gov.br/CCVIL/_ato2004_2006/Lei/L11340.htm>. Acesso em: 10 de agosto de 2007.

BRASIL. Presidência da República. Plano Nacional de Políticas para as Mulheres. Secretária Especial de políticas para as Mulheres - SPM. Disponível em: <http://www.presidencia.gov.br/spmulheres/> Acesso em: 15 de setembro de 2007.

BRASIL. SEPAVI - Seção de Atenção Psicossocial de Violência Intrafamiliar. Núcleo Psicossocial Forense - NUPS/TJDFT, Brasília, 2002.

CARREIRA, D. e PANDJIARJIAN, M. Vem pra Roda! Vem pra Rede! Guia de apoio à construção de rede de serviço para o enfrentamento da violência contra a mulher. São Paulo: Rede Mulher de Educação (RME), com apoio da GTZ - Cooperação Técnica Alemã e da UNIFEM - Fundo de Desenvolvimento das Nações Unidas para a Mulher, 2003. 
CAVALCANTI, Stela Valéria Soares de Farias. Violência Doméstica: análise da Lei "Maria da Penha”, No 11.340/06. Salvador: Ed. Podivm, 2007. pp. 25 - 41, 47 - 57, 155 193.

CFEMEA. Lei Maria da Penha: do papel para a vida. Comentários à Lei 11.340/2006 e sua inclusão no ciclo orçamentário. Brasília: Centro Feminista de Estudos e Assessoria, 2007. pp. $03-68$.

COIMBRA, Marcos Antônio. Será que o marxismo responde à pergunta de como surgem as políticas sociais? Política social e combate à pobreza, Rio de Janeiro, editora Zahar, 1987, pp.105 - 126.

DIEHL, Arthur. O homem e a nova mulher: novos padrões sexuais de conjugalidade. In: Família em cena. Petrópolis: Vozes, 2002. pp. 135 - 158. Disponível em $<$ http://www.scielo.br/scielo.php?script=sci_arttex\&pid=s0103166x200500200003\&Ing=e n\&nrm=iso\&tl.htm>. Acesso em: 05 de dezembro de 2007.

DINIZ, Gláucia; PONDAAG, Miriam. Explorando significados do silêncio e do segredo nos contextos da violência doméstica. In: Direitos Humanos e violência: desafios da Ciência e da Prática. Fortaleza: Fundação Konrad Adenauer, 2004. pp. 171 - 185.

EDWARDS, Griffith; MARSHALL, E. Jane; COOK, Christopher C. Complicações sociais do beber excessivo. In $\mathrm{O}$ tratamento do alcoolismo: um guia para profissionais de saúde. Porto Alegre: Editora Artes Médicas, 1999.

FALEIROS, Vicente de Paula. As estratégias nas mediações de relações complexas em rede. In: Estratégias em Serviço Social. São Paulo: Cortez, 2. ed, 1999. pp. 53 - 63.

FALEIROS, Vicente de Paula e FALEIROS, Eva Silveira. Formas de Violência. In: Escola que protege: enfrentando a violência contra crianças e adolescentes. Coleção Educação para Todos. 1. ed. Brasília: Ministério da Educação, 2007. pp. 25 - 51.

(Coords). Marco Referencial Teórico. In: Circuito e Curtos - Circuitos: atendimento, defesa e responsabilização do abuso sexual contra crianças e adolescentes. CECRIA. Brasília: Veras Editora, 2001. pp. 15 - 35.

FARAH, Marta Ferreira Santos. Políticas públicas e gênero. In: Políticas Publicas e igualdade de gênero. São Paulo: Cadernos da Coordenadoria Especial da Mulher, 2004. pp. $127-142$.

FREITAS, Juliana Garcia de. Breve histórico dos movimentos feministas/ A construção do conceito de gênero. In: Gênero e Violência "Uma reflexão sobre as mulheres na Casa Abrigo”. Brasília: Universidade de Brasília, 1998. pp. 03 - 10. 
GHESTI, Ivânia; ROQUE; Elizângela Caldas Barroca; MOURA, Marília Lobão Ribeiro. Breve Análise Psicossocial dos casos inaugurais de $1^{\text {a }}$ Vara de Violência Familiar e Doméstica contra a Mulher do TJDFT. In: Novos Paradigmas na Justiça Criminal: relatos de experiência do Núcleo Psicossocial Forense do TJDFT. 1. ed. Brasília, 2006. pp. $368-388$.

GÖSSMANN, Elisabeth (org.); PEREIRA, Carlos Almeida. Dicionário de Teologia Feminista. Petrópolis: Vozes, 1996. pp. $394-400$.

MACHADO, Lia Zanotta; MAGALHÃES, Maria Tereza Bossi de Magalhães. Violência conjugal: os espelhos e as marcas. In: Violência, gênero e crime no Distrito Federal. Brasília: Paralelo 15, Editora Universidade de Brasília, 1999. pp. 173 - 200.

MARTIN, Gabriela; PESSIS, Anne-Marie. Das origens da desigualdade de gênero. In: Marcadas a ferro: violência contra a mulher, uma visão interdisciplinar. Brasília: Secretária Especial de Políticas para as Mulheres, 2005. pp. 17 - 22.

MENDES, Eugênio Vilaça. A implantação das redes de atenção à saúde. Belo Horizonte: Secretária de Estado de Saúde de Minas Gerais/ Superintendência de Atenção à Saúde, 2007. pp. 05 - 53.

MINAYO, M. C. S. A violência social sob a perspectiva da saúde pública. Cadernos de Saúde Pública, Rio de Janeiro, N. 10 (Suplemento 1), 1993. pp. 07 - 18.

OLIVEIRA, Lianne Carvalho de. O surgimento da noção de gestão partilhada e em rede como novo modelo de estruturação da política social. In: $O$ atendimento às mulheres presas na Penitenciária Feminina do Distrito Federal: uma análise do ideário da gestão partilhada e em rede das políticas sociais na década de 1990. Brasília: Universidade de Brasília, 2003. pp. 28 - 35.

PINTO, Céli Regina Jardim. Uma história do feminismo no Brasil. São Paulo: Editora Fundação Perseu Abramo, 2003. 119p.

QUEIROZ, Fernanda Marques de. Violência contra a mulher: o “pessoal é político”. Mossoró: Expressão, Universidade do Estado do Rio Grande do Norte, 2002. pp. 29 - 42. Disponívelem:<http://200.164.64.132/pdf/RevistaExpressao/RevistaEspressao_2002_3pdf > Acesso em: 15 de dezembro de 2007.

SAFFIOTI, Heleieth I. B. Já se mete a colher em briga de marido e mulher. São Paulo, 1999. Disponível em <http://www.scielo.br/pdf/spp/v13h4a08.pdf>. Acesso em: 25 de outubro de 2007.

Contribuições feministas para o estudo da violência de gênero. In: Cadernos Pagu, São Paulo, N. 16, 2001. pp. 115 - 136. 
SANTOS, José Vicente Tavares dos. Por uma sociologia da conflitualidade no tempo da globalização. Rio Grande do Sul: Ed. Universidade Federal do Rio Grande do Sul, 1999. pp. $11-39$.

SANTOS, Patrícia da Conceição. Violência contra a Mulher no Distrito Federal: causas e dimensões. Brasília: Universidade de Brasília, 2001. pp. 05 - 25.

SOARES, Bárbara Musumeci. Aspectos da violência doméstica no Brasil: experiência invisível. In: Mulheres Invisíveis: violência conjugal e as novas políticas de segurança. Rio de Janeiro: Civilização Brasileira, 1999. pp. 45 - 61.

SCOTT, Joan. Gênero: uma categoria útil de análise histórica. Recife, 2. ed. Sos Corpo. 1995. pp.71-99.

VELHO, Gilberto. Violência, reciprocidade e desigualdade: uma perspectiva antropológica. In: VELHO, G. e Alvito, M. (orgs.). Cidadania e violência. Rio de Janeiro: Editoras UFRJ; FGV, 1996. 


\section{Anexos}

Anexo I - Análise dos serviços de atendimento às mulheres vítimas de violência conjugal no DF

Local e Data de Realização:

Número do Questionário:

Técnico Responsável pelo processo:

Pesquisadora: Dayane Cristina Moreira Xavier

\section{I)Perfil das entrevistadas}

1. Idade:
a.( ) 18 a 39 anos.
b.( ) 40 a 60 anos.
c.( ) 61 anos ou mais.

2. Grau de Instrução:

a. ( ) Não alfabetizado.

b.( ) Educação Básica - (Supletivo $1^{\circ}$ e $2^{\circ}$ graus).

c.( ) Ensino Fundamental - (1 a a $9^{\mathrm{a}}$ séries).

d.( ) Ensino Médio - (1 $1^{\mathrm{a}}$ a $3^{\mathrm{a}}$ séries do $2^{\mathrm{o}}$ grau).

e.( ) Educação Superior.

f.( ) Pós-Graduação.

3. Local de moradia no DF:

a.( )Águas Claras.

b.( )Brazlândia.

c.( )Candagolândia.

d.( )Ceilândia.

e.( )Cruzeiro.

f.( )Gama.

g.( )Guará I ou II.

h.( )Lago Norte.

i.( )Lago Sul.

j.( )Núcleo Bandeirante.

l.( ) Paranoá.

m.( )Park Way.

n.( )Planaltina.

o.( )Plano Piloto.

p.( )Recanto das Emas.

q.( )Riacho Fundo.

r.( )Samambaia.

s.( )Santa Maria.

t.( )São Sebastião.

u. ( )Sobradinho.

v.( )Taguatinga.

x.( )Outra Satélite. Especificar:

z. ( )Cidade do Entorno. Especificar:

4. Tempo de residência no Distrito Federal:

a. () Sempre. A vida toda.

b.( ) Entre 00 e 05 anos.

c.( ) Entre 06 e 10 anos.

d.( ) Entre 11 e 15 anos.

e.( ) Mais de 15 anos.

5. Se não é natural do DF, local onde residia antes (cidade/Estado): 
6. Estado civil:

a.( ) Solteira.

b. ( ) Casada.

c.( ) Separada de fato.

d. () Separada judicialmente.

e.( ) Divorciada.

f.( ) Concubinato.

g.( ) Viúva.

7. Vive/u há quanto tempo com o companheiro:

a.( ) Menos de 01 ano.

b.( ) Entre 01 e 05 anos.

c.( ) Entre 06 e 10 anos.

d.( ) Entre 11 e 15 anos.

e.( ) Entre 16 e 20 anos.

f.( ) Entre 21 e 25 anos.

g.( ) Acima de 25 anos. Especificar:

8. Situação da moradia em que reside:

a.( ) Própria.

b. ( ) Cedida.

c.( ) Alugada.

d. ( ) Funcional.

e. () Mora com terceiros.

f.( ) Mora com os pais

g.( ) Outra. Especificar:

9. Situação ocupacional:
a.( ) Desempregada.
b.( ) Autônoma.
c.( ) Aposentada.
d.( ) Estudante.
e.( ) Empregada.
f.( ) Do lar.
g.( ) Pensionista.

10. Se empregada, possui vínculo empregatício formal:

a.( ) $\mathrm{Sim}$

b.( ) Não

11. Se desempregada, por quanto tempo:

a.( ) Menos de 01 ano

b.( ) Entre um e 05 anos

c.( ) Entre 06 e 10 anos

d.( ) Outra. Especificar:

12. Renda Pessoal (em salários mínimos):

a.( ) Menos de um salário

b.( ) Entre 1 e 3 salários

c.( ) Entre 4 e 8 salários

d.( ) Entre 8 e 12salários

e.( ) Acima de 12 salários

\section{II) Dados gerais da família}

13. Renda Familiar (em salários mínimos):

a. ( ) Menos de um salário

b.( ) De 1 a 3 salários

c.( ) De 4 a 8 salários

d.( ) De 8 a 12salários 
e.( ) Acima de 12 salários

14. Para quantos membros. Especificar:

15. Identificação dos moradores da casa:

\begin{tabular}{|l|l|l|}
\hline Identificação & Parentesco & Idade \\
\hline 1. & & \\
\hline 2. & & \\
\hline 3. & & \\
\hline 4. & & \\
\hline 5. & & \\
\hline 6. & & \\
\hline 7. & & \\
\hline 8. & & \\
\hline
\end{tabular}

III) Relacão entre autor e vítima

16. Tipo de relação entre o autor do fato e a vítima:

a. ( ) marido e mulher

b.( ) ex-marido e ex-mulher

c.( ) companheira (a)

d.( ) ex- companheiros (as)

e.( ) namorados (as)

f.( ) ex-namorados (as)

g.( ) noivos (as)

h.( ) ex- noivos (as)

i. ( ) extraconjugal

j.( ) filho (a) e mãe

l.( ) mãe e filha

m.( ) pai e filha

n.( ) irmãos

o.( ) Outra. Especificar:

17. O episódio de violência é uma reincidência (já foram realizadas outras denúncias):

a.( ) Sim

b.( ) Não

\section{IV) Situação de Saúde}

18. Possui algum problema de saúde/mulher:

a.( ) Cardiopatias

b. ( ) Hipertensão arterial

c.( ) Diabetes

d.( ) Abuso/dependência de álcool

e.( ) Abuso/dependência de drogas. Especificar:

f.( ) Doenças sexualmente transmissíveis. Especificar:

g. ( ) Transtornos mentais. Especificar:

h.( ) Outra. Especificar:

19. Possui algum problema de saúde/homem:

a.( ) Cardiopatias

b. ( ) Hipertensão arterial

c.( ) Diabetes

d.( ) Abuso/dependência de álcool

e. ( ) Abuso/dependência de drogas. Especificar:

f.( ) Doenças sexualmente transmissíveis. Especificar:

g. ( ) Transtornos mentais. Especificar: 
h.( ) Outra. Especificar:

\section{V) Dados gerais do processo}

20. Data/Mês de entrada do "caso" no SERAV para acompanhamento:

a.( ) Outubro de 2006.

b. ( ) Novembro de 2006.

c.( ) Dezembro de 2006.

d. () Janeiro de 2007.

e.( ) Fevereiro de 2007.

f.( ) Março de 2007.

g.( ) Abril de 2007.

h.( ) Maio de 2007.

21. Data/Mês de encerramento do acompanhamento do "caso" no SERAV:

a. ( ) Outubro de 2006.

b. ( ) Novembro de 2006.

c.( ) Dezembro de 2006.

d.( ) Janeiro de 2007.

e.( ) Fevereiro de 2007.

f.( ) Março de 2007.

g.( ) Abril de 2007.

h.( ) Maio de 2007.

i.( ) Junho de 2007.

j.( ) Julho de 2007.

l.( ) Agosto de 2007.

m. () Setembro de 2007.

n. () Outubro de 2007.

o.( ) Novembro de 2007.

p.( ) Outro. Especificar:

22. Tempo do acompanhamento da partes no SERAV (determinado no termo de audiência):

a.( ) Indeterminado.

b.( ) A ser determinado pelo SERAV.

c.( ) menos de 01 mês.

d.( ) 01 mês.

e.( ) 02 meses.

f.( ) 03 meses.

g.( ) 04 meses.

h.( ) 05 meses.

i.( ) 06 meses.

j.( ) Mais de 06 meses. Especificar:

\section{VI) Encaminhamento para rede}

23. Alguma das partes diretas do processo recebeu encaminhamento do SERAV para outra (s) instituição/programa (s):

a.( ) Nenhuma da partes.

b.( ) Mulher.

c.( ) Homem.

d.( ) Ambos (as).

e.( ) Outra. Especificar:

24. Para qual instituição/ programa a mulher foi encaminhada:

a. () Programa Margarida

b.( ) Projeto Violeta

c.( ) Casa Abrigo

d.( ) Grupo de Casal. Especificar: 
e.( ) Terapia Individual. Especificar:

g.( ) Conselho de Direitos da Mulher - CDM. Especificar:

h.( ) Grupo Mulheres que Amam Demais - MADA. Especificar:

i. ( ) Terapia Comunitária. Especificar:

j. ( ) Outra. Especificar:

25. Para qual instituição/ programa o homem foi encaminhado:

a. ( ) Programa Margarida

b.( ) Projeto Violeta

c.( ) Casa Abrigo

d.( ) Grupo de Casal. Especificar:

e.( ) Terapia Individual. Especificar:

f.( ) Conselho de Direitos da Mulher - CDM. Especificar:

g. ( ) Grupo Mulheres que Amam Demais - MADA. Especificar:

h.( ) Terapia Comunitária. Especificar:

i.( ) Outra. Especificar:

26. Para qual (s) instituição/ programa ambos (as) foram encaminhados (as):

a.( ) Programa Margarida

b.( ) Projeto Violeta

c.( ) Casa Abrigo

d.( ) Grupo de Casal. Especificar:

e.( ) Terapia Individual. Especificar:

f. ( ) Conselho de Direitos da Mulher - CDM. Especificar:

g. ( ) Grupo Mulheres que Amam Demais - MADA. Especificar:

h.( ) Terapia Comunitária. Especificar:

i.( ) Outra. Especificar:

\section{Anexo II - Termo de Consentimento}

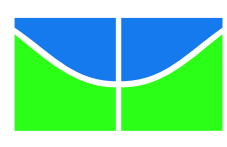

\section{Universidade de Brasília - UnB \\ Instituto de Ciências Humanas - IH \\ Departamento de Serviço Social - SER}

\section{Termo de Consentimento Livre e Esclarecido}

Você está sendo convidado a participar da pesquisa "Os serviços de atendimento às mulheres vítimas de violência conjugal no DF: o olhar da equipe do NUPS/SERAV (TJDFT)”.

A sua participação não é obrigatória, e a qualquer momento você poderá desistir. As informações obtidas através desta pesquisa serão confidenciais e asseguramos o total sigilo da sua participação. Os dados não serão divulgados de forma a possibilitar sua identificação (informar, de acordo com os métodos utilizados na pesquisa, como a pesquisadora protegerá e assegurará sua privacidade).

Sua participação consistirá em responder 18 perguntas que serão anotadas e gravadas, que logo após a análise serão descartadas. Você receberá uma cópia deste termo onde consta o telefone e o endereço eletrônico da pesquisadora principal e poderá tirar suas dúvidas sobre o projeto e sua participação, agora ou a qualquer momento.

Pesquisadora:

Dayane Cristina Moreira Xavier.

Telefone: (61) 9295-9770.

E-mail: daym.xavier@gmail.com 
Declaro que entendi os objetivos da minha participação na pesquisa e concordo em participar.

Anexo III - Análise dos serviços de atendimento às mulheres vítimas de violência conjugal no DF

Local e Data de Realização:

Número do Questionário:

Pesquisadora: Dayane Cristina Moreira Xavier

\section{I)Perfil dos entrevistados}

16. Idade:

a.( ) 18 a 39 anos

b.( ) 40 a 60 anos

c.( ) 61 anos ou mais

17. Sexo:

a.( ) Feminino

b.( ) Masculino

18. Titulação:

a.( ) Graduado

b.( ) Especialização. Especificar:

c.( ) Mestrado. Especificar área:

d.( ) Doutorado. Especificar área:

\section{II) Dados profissionais}

19. Há quanto tempo trabalha no SERAV (antigo NUPS)?

a.( ) Menos de 01 ano

b.( ) Entre 01 e 03 anos

c.( ) Entre 04 e 06 anos

d. () Mais de 06 anos

20. Trabalhava com a temática da violência antes?

a.( ) Sim

b. ( ) Não

21. Em caso positivo, que tipo de instituição trabalhava anteriormente?
a.( ) Saúde
b.( ) Judiciário
c.( ) Assistência
d.( ) ONG
e.( ) Outro. Especificar:

22. Recebeu capacitação nos últimos 05 anos sobre?

a.( ) Gênero

b.( ) Lei Maria da Penha

c.( ) PNPM

d.( ) Política social

e.( ) Gestão pública

f.( ) Família

g. ( ) Segurança pública

h.( ) Direitos humanos 
i.( ) Assistência

j. ( ) Saúde

l. ( ) Outro. Especificar:

III) Procedimentos do SERAV

23. Quais foram os principais procedimentos adotados por você nos casos de violência conjugal? (enumere as três alternativas principais)

a.( ) Atendimentos individuais com as partes.

b.( ) Atendimentos de casal/ ex - casal.

c.( ) Atendimentos familiares.

d.( ) Atendimentos em grupo (para uma das partes e/ ou ambos)

e.( ) Encaminhamento específico somente vítima.

f.( ) Encaminhamento específico somente autor.

g.( ) Encaminhamento específico para ambos.

h.( ) Outro. Especificar:

\section{III) Procedimentos de Encaminhamento}

24. Quais os principais procedimentos adotados por você, para encaminhar as partes para os serviços de atendimento? (enumere as duas alternativas principais)

a.( ) Contato telefônico para programa/instituição.

b.( ) Contato pessoal com o programa/instituição.

c.( ) Formulário próprio de encaminhamento.

d.( ) Telegrama de encaminhamento para programa/instituição.

e.( ) Relatório de encaminhamento para programa/instituição.

f.( ) Outro. Especificar:

\section{IV) Avaliação dos Procedimentos de Encaminhamentos}

25. Como você avalia os procedimentos adotados por você nos encaminhamentos para os serviços?

a.( ) Satisfatórios

b. ( ) Insatisfatórios

c.( ) Outro. Especificar:

26. Em caso de insatisfatório. Na sua avaliação quais procedimentos adotados seriam mais satisfatórios?

a.( ) Contato telefônico para programa/instituição.

b.( ) Contato pessoal com o programa/instituição.

c.( ) Formulário próprio de encaminhamento.

d.( ) Telegrama de encaminhamento para programa/instituição.

e.( ) Relatório de encaminhamento para programa/instituição.

f.( ) Outro. Especificar:

\section{IV) Serviços Utilizados}

12. Para qual (s) da (s) instituição/ programa listados a seguir, você mais encaminha os casos de violência conjugal? (enumere as três alternativas principais)

a. () Programa Margarida

b.( ) Projeto Violeta

c.( ) Casa Abrigo

d.( ) Grupo de Casal. Especificar (público, privado, social):

e.( ) Terapia Individual. Especificar (pública, privada, social):

f.( ) Conselho de Direitos da Mulher - CDM.

g.( ) Grupo Mulheres que Amam Demais - MADA. Especificar (local):

h.( ) Terapia Comunitária (mínimo três): Especificar:

i.( ) Outra. Especificar: 


\section{V) Avaliação dos Serviços Utilizados}

13. Na sua opinião qual (s) destes serviços ajudou a modificar/eliminar a situação de violência vivida pelo casal? (enumere as três alternativas principais)

a.( ) Programa Margarida

b.( ) Projeto Violeta

c.( ) Casa Abrigo

d.( ) Grupo de Casal. Especificar (público, privado, social):

e.( ) Terapia Individual. Especificar (pública, privada, social):

f.( ) Conselho de Direitos da Mulher - CDM.

g. ( ) Grupo Mulheres que Amam Demais - MADA. Especificar (local):

h.( ) Terapia Comunitária (mínimo três): Especificar:

i.( ) Outra. Especificar:

14. Na sua opinião qual a vantagem/importância dos serviços que você citou acima?

1.

2.

3.

15. Você recebeu retorno destes programas/instituições sobre os casos encaminhados?

a.( ) sim. Especificar o (s) serviço (s):

b.( ) não

16. Se sim, qual (s) foram as principais formas utilizadas pelos programas/instituições para dar retorno dos casos para o SERAV? (enumere duas alternativas principais).

a.( ) Contato telefônico.

b.( ) Contato pessoal.

c.( ) Formulário próprio do serviço.

d.( ) E-mail especifico do acompanhamento.

e.( ) Relatório do acompanhamento do caso.

f.( ) Outro. Especificar:

17. Você tem alguma sugestão/crítica referente aos atendimentos destes serviços

a.( ) $\operatorname{sim}$

b.( ) não

18. Se sim, qual (s)? 